\title{
THE POSSIBILITY OF USING JERK PARAMETERS AS SEISMIC INTENSITY MEASURE
}

\author{
Abdulhameed A. Yaseen ${ }^{1}$, MeZgeen S. Ahmed and Yaman S. S. Al-Kamaki \\ Dept. of Civil Engineering, College of Engineering, University of Duhok, Kurdistan Region-Iraq
}

(Accepted for Publication: December 8, 2020)

\begin{abstract}
It is a common procedure to use a single parameter because of its simplicity to represent the seismic action in a particular region and describe its complex nature. This single parameter generally is known as ground motion intensity measure IM. The time derivative of acceleration, commonly known as jerk, is met in a limited number of such studies and specifically in earthquake engineering. For that purpose, this paper presents a study on the performance of using seismic jerk as ground motion IM. Several typical RC frame buildings of different numbers of stories were selected. The nonlinear time-history analysis is performed while the buildings are exposed to twenty-seven natural earthquake records using ETABS software. The maximum displacement at the top of the building is selected as the structural response parameter. Several widely used IMs were defined in addition to the jerk and its based parameters. After performing a large number of nonlinear analyses and applying machine learning, best feature subsets that present relation between response parameter and considered intensity measures were obtained. For structures with low nonlinearity in behavior, jerk- based parameters were shown to be effective.
\end{abstract}

KEYWORDS: Ground motion intensity measure; Jerk; Time derivation of acceleration; RC buildings; Masonry Buildings.

\section{INTRODUCTION}

$\mathbf{F}$ or the reason of seismic vulnerability evaluation and to characterize the possibility of damage initiated by seismic ground motion in terms of fragility curves, a ground-motion parameter called an intensity measure (IM) is typically utilized. In a broad sense, it is a familiar technique to use a single parameter because of its simplicity to represent the seismic action in a specific area and designate its complex nature.

A successful IM should be able to reliably evaluate the structural response without additional ground-motion information such as magnitude or epicentral distance and etc. During years, some significant IMs have been extracted and derived by researchers (e.g. Housner, 1952; Housner\& Jennings, 1964; Arias, 1970; Shome et al., 1998 and etc.) using convenient mathematical methods applied to time histories. These parameters can be categorized based on the time histories that they are derived from and are known as acceleration-, velocity-, or displacement-based intensity measures (Riddell, 2006; Buratti, 2012). The majority of these parameters calculate one of the ground-motion characteristics: the amplitude, duration or frequency content of ground motion. Nevertheless, there are roughly other parameters that are established on a combination of the above mentioned characteristics; these parameters are typically identified as energybased parameters. The duration is another essential characteristic of ground motion that may affect the level of damage experienced by a structure. Conversely, several investigations (e.g., Riddell, 2006; Nanos, 2011; Buratti, 2012; Elenas, 2013) have asserted that various IMs may have altered abilities in predicting structural reactions when being used as a damage state. Thus, one of the most vital purposes put forth in these researches was to ascertain the groundmotion parameter that is best associated with damage which is, in turn, a function of the structural behavior.

Even though study of the those widely known parameters can also be improved in order to grow the spectra characteristic of ground motions, 'jerk' is a measure not intensively addressed as yet. By the abrupt change of building acceleration, the motion may assume an explosive character. During the following decades of the nineteenth century, that dynamic

a.yaseen@uod.ac, ezgeen@uod.ac, yaman.alkamaki@uod.ac ${ }^{1}$ Corresponding author: College of Engineering, University of Duhok, Kurdistan Region, Iraq 
phenomenon of motion was identified in many applications of practical interest, and much later in the Seismic Engineering. Currently, it is called jerk in English (Sofronie, 2017). Theoretically, jerk is defined as the changing rate of acceleration with respect to time (Schot,1978), and its international unit is $\mathrm{m} / \mathrm{s}^{3}$. In current years, jerk is applied in the tracking and positioning for Global Positioning System (GPS), the automatic control of high-speed machines, the high-speed dynamic vehicle tracking, and comfort assessment for high speed trains and elevators (Toshiyuki et al,2009; Liu et al,1999; Hrovat and Hubbard,1987).

In structural and earthquake engineering field, a number of investigations tried to examine the influence of jerk on structure's safety and strength. For example, HE et al. (2011), studied the characteristics of jerk response spectra based on the influencing parameters, such as an amplification factor, a site condition, a reduction factor and a ductility factor. The study consequences illustrate that jerk influences the building structures with short or middle periods more observably, and the impact responses can be decreased considerably when the structural ductility is improved; the impact of jerk on long-period structures can be disregarded. Furthermore, HE et al. (2015) confirmed the results of HE et al. (2011) study and asserted that the jerk spectrum has comparable behavior as acceleration spectrum in general, and the amplitude is in relation to the predominant period, particularly for structures with short or medium period. Similarly, Tong et al. (2005) asserted that the large acceleration pulses are surrounded by large TDoA (the time derivative of acceleration of strong ground motion) spikes. They presented a basic evaluation of TDoA and showed that TDoA is one of the essential contributing parameters to some of the reaction difficulties that limit the capability of people to move usually throughout strong earthquakes. They also indicated that peak ground jerk PGJ and peak ground acceleration PGA are kinetically correlated. Large TDoA allied with strong ground acceleration may consequence in nonuniform dynamic loading caused by the stress wave propagation. This outcome may source stress concentration and local damage (Tong et al., 2005). According to the Sofronie (2017), the dislocations, always occur around local structural imperfections by high concentrations of stresses. Each construction material, elastic or non-elastic, has its own intrinsic time of dislocation when stresses are randomly redistributed. That time has to be compared with the jerk's time of action because the action time of jerks is too short for developing deformations. Only then a valid conclusion on the dynamic phenomenon of amplification could be correctly drawn. He asserted that, generally, the seismic jerks occur in the case of buildings with unbalanced masses.

As abovementioned, unlike acceleration, velocity, and displacement, the time derivative of acceleration of ground motion, Jerk, has not been comprehensively addressed for various seismic source mechanisms, ground motion characteristics and engineering applications (Tong et al., 2005). Additionally, the authors couldn't find even a study regarding the role and importance of jerk as ground-motion IM. Hence, the current study tries to find the answer of this question "Can Jerk Parameters Be Used as Seismic Intensity Measures?"

\section{METHODOLOGY}

A four stage procedure followed to gain the main objectie of this study as shown in Figure 1. Each stage has been intensively discussed in the following sections.

a.yaseen@uod.ac, mezgeen@uod.ac, yaman.alkamaki@uod.ac 


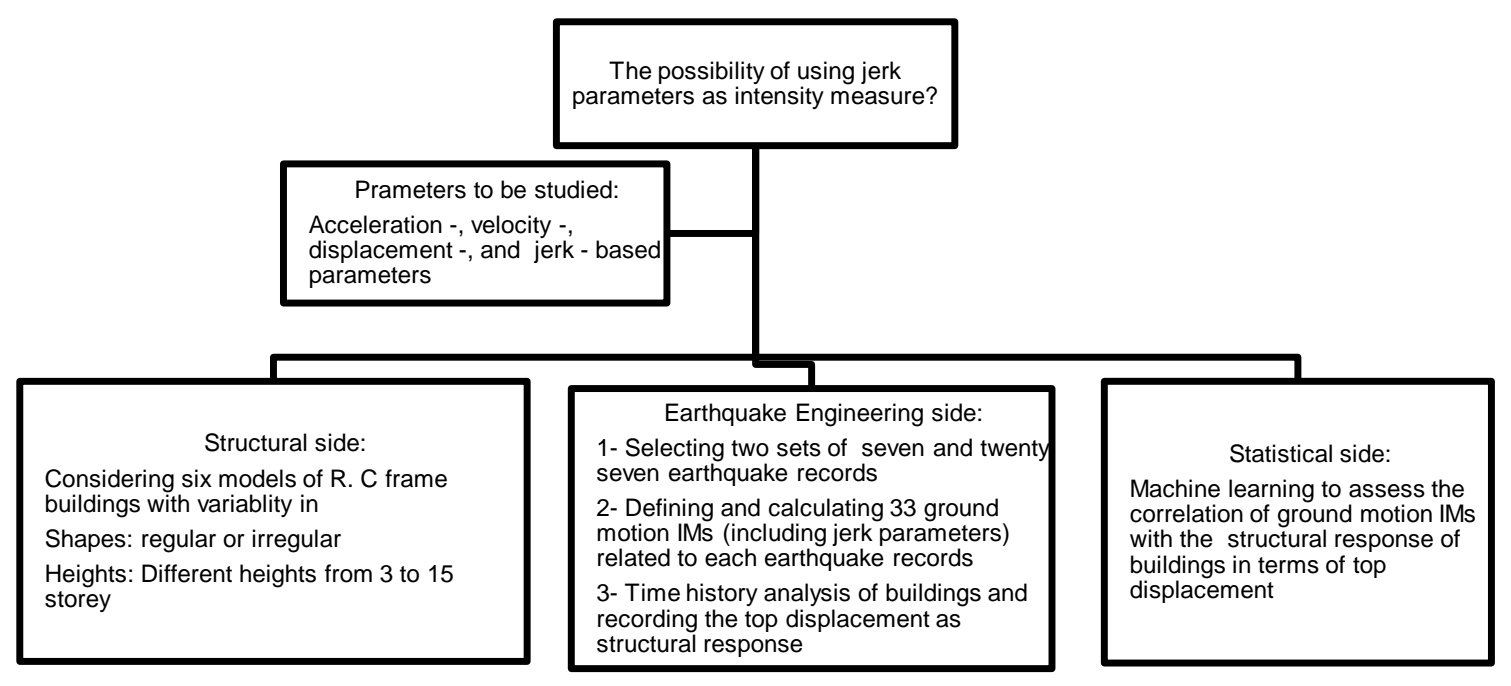

Fig. (1): Flowchart showing the methodology used in the current study

\subsection{Ground-motion IMs considered in the present study}

To examine which ground-motion IMs are most significant for a given structure in a particular location, the effect of multiple relevant accelerograms must be considered. The IMs chosen for consideration and associated with each accelerogram must be also determined. It is then necessary to determine the correlation between each IM and the damage index related to the structural response of buildings. The IM giving the highest correlation with damage index is the IM that should be chosen. This study has considered a range of widely used groundmotion IMs as presented in Table 1. Furthermore, in addition to the IMs given in Table 1, and toward the study of the importance of jerk as a ground motion IM, the current study defined some new parameters (Table 2) considering the Jerk time history of each earthquake record selected by this study. SeismoSignal (SeismoSoft, 2018) software was used to calculate all the ground-motion IMs.

Table (1): A number of commonly used Ground-motion IMs considered in the current study

\begin{tabular}{|c|c|}
\hline IMs* & Name \\
\hline $\begin{array}{l}\text { Acceleration- } \\
\text { based }\end{array}$ & $\begin{array}{l}\text { Peak ground acceleration (PGA), root mean square of acceleration (ARMS), Arias intensity (IA), } \\
\text { characteristic intensity (IC), cumulative absolute velocity (CAV), acceleration spectrum intensity (ASI), } \\
\text { sustained maximum acceleration (SMA), effective design acceleration (EDA), A95 parameter, and } \\
\text { average spectral acceleration } \mathrm{Sa}(\text { ave.) }\end{array}$ \\
\hline Velocity-based & $\begin{array}{l}\text { Peak ground velocity (PGV), root mean square of velocity (VRMS), specific energy density (SED), } \\
\text { velocity spectrum intensity (VSI), sustained maximum velocity (SMV), and Housner intensity (IH) }\end{array}$ \\
\hline $\begin{array}{c}\text { Displacement- } \\
\text { hread }\end{array}$ & Peak ground displacement (PGD), root mean square of displacement (DRMS) \\
\hline Duration & Predominant period (TP) and mean period (Tm) \\
\hline Others & Impulsivity index (IP Index) and damage index \\
\hline
\end{tabular}

* The reader may refer to Kramer (1996), Yaseen (2015), and SeismoSoft (2018) for an explicit explanation of the examined IMs.

a.yaseen@uod.ac, mezgeen@uod.ac, yaman.alkamaki@uod.ac ${ }^{1}$ Corresponding author: College of Engineering, University of Duhok, Kurdistan Region, Iraq 


\subsubsection{Jerk and Jerk based Parameters}

About eleven jerk based parameters were defined in the current study. The definition of these parameters and their mathematical expression are given in this section and are shown in Table 2.

\subsubsection{Jerk}

Currently, jerk sensors are not normally obtainable; thus, attaining jerk information becomes the crucial first step. In this study, and according to (Tong et al., 2005), the jerk j(t) time series are calculated from ground acceleration records by the following mid-point differentiation formula.

$j\left(t_{i}\right)=\frac{\mathrm{a}\left(\mathrm{t}_{\mathrm{i}+1}\right)-\mathrm{a}\left(\mathrm{t}_{\mathrm{i}-1}\right)}{2 \Delta \mathrm{t}}(\mathrm{i}=2, \ldots, \mathrm{N}-1)$ Equation 1

Wherea $\left(t_{i}\right)$ is the acceleration time series; $N$ is the total number of sampling points; and $\Delta \mathrm{t}=$ $\mathrm{t}_{\mathrm{i}}-\mathrm{t}_{\mathrm{i}-1}$ is the time interval between two neighboring points. The $\mathrm{j}\left(\mathrm{t}_{\mathrm{i}}\right)$ is the average jerk in the time interval $2 \Delta \mathrm{t}$ between the time points $\mathrm{i}-1$ and $\mathrm{i}+1$.

\subsubsection{Jerk energy}

Based on the mathematical expression form of the acceleration energy developed by Qiao (1990), An et al. (2014) presented the so-called jerk energy (JE) that is well-defined as the natural logarithm of the sum of the squares of the sampled average jerk over the entire time history. Based on the An et al. (2014) definition of JE and considering equation 1, in this study, equation 2 is used to calculate the JE. $J E_{i}=\log \sum_{i=1}^{N-1} j\left(t_{i}\right)^{2}$ Equation 2

\subsubsection{Jerk - bracketed duration}

Afterward the bracketed duration of acceleration, the duration of strong ground jerk is reflected as the time span between the first and the last peak within a certain threshold. The duration defined in this research may be interpreted as the time range where jerk makes the human body feel extremely uncomfortable. According to the Tong et al. (2005) review of different studies, if the jerk is larger than 2000 $\mathrm{cm} / \mathrm{s}^{3}(2 \mathrm{~g} / \mathrm{s})$ (within about $10 \mathrm{~Hz}$ ), people will become very uncomfortable. So, the threshold of jerk - bracketed duration was set to be 2000 $\mathrm{cm} / \mathrm{s}^{3}(2 \mathrm{~g} / \mathrm{s})$ in this study. Table 2 show all jerkbased parameters undertaken in the present investigation.

Table (2): Jerk-based parameters considered in the current study

\begin{tabular}{|c|c|c|}
\hline $\begin{array}{c}\text { Jerk-based } \\
\text { IMs(abbreviations) }\end{array}$ & Name & Mathematical expression \\
\hline $\mathrm{PGJ}\left(\mathrm{cm} / \mathrm{s}^{3}\right)$ & Peak Ground Jerk & $\max |j(t)|$ \\
\hline $\mathrm{T}_{\max .}(\mathrm{s})$ & Time of maximum Jerk & \\
\hline JRMS $\left(\mathrm{cm} / \mathrm{s}^{3}\right)$ & Root mean square of jerk & $J_{R M S}=\sqrt{\frac{1}{t_{t o t}} \int_{0}^{t_{t o t}}[j(t)]^{2} d t}$ where $t_{\text {tot }}=$ total time of jerk time history \\
\hline $\mathrm{IAJ}\left(\mathrm{m} / \mathrm{s}^{3}\right)$ & Jerk Arias Intensity & $I_{j}=\frac{\pi}{2 g} \int_{0}^{t_{t o t}}[j(t)]^{2} d t \quad$ where $\mathrm{g}=$ gravitational constant \\
\hline ICJ & $\begin{array}{l}\text { Jerk- Characteristic } \\
\text { Intensity }\end{array}$ & $I_{c}=\left(U_{R M S}\right)^{\frac{3}{2}} \sqrt{t_{t o t}}$ \\
\hline $\mathrm{JSI}\left(\mathrm{cm} / \mathrm{s}^{2}\right)$ & Jerk- Spectrum Intensity & $J S I=\int_{0.1}^{0.5} S_{j}(\varepsilon=0.05, T) d T$ where $\mathrm{Sj}=$ Spectral Jerk \\
\hline $\mathrm{SMJ}\left(\mathrm{cm} / \mathrm{s}^{3}\right)$ & Sustained Maximum Jerk & $\begin{array}{l}\text { This parameter gives the sustained maximum jerk during three cycles, } \\
\text { and is defined as the third highest absolute value of jerk in the jerk } \\
\text { time history }\end{array}$ \\
\hline $\begin{array}{l}\text { J95 parameter } \\
\left(\mathrm{cm} / \mathrm{s}^{3}\right)\end{array}$ & & $\begin{array}{l}\text { The jerk level below which } 95 \% \text { of the total Jerk Arias intensity is } \\
\text { contained }\end{array}$ \\
\hline $\mathrm{S}_{\mathrm{j}}$, avg $\left(\mathrm{cm} / \mathrm{s}^{3}\right)$ & & $\begin{array}{l}\text { The Average Spectral Jerk is computed as the geometric mean of the } \\
\text { spectral pseudo-jerk ordinates for a } 5 \% \text { damping }\end{array}$ \\
\hline $\mathrm{Tb}(2000)(\mathrm{s})$ & Jerk- bracketed duration & $\begin{array}{l}\text { The total time elapsed between the first and the last excursions of a } \\
\qquad 2000 \mathrm{~cm} / \mathrm{s}^{3} \text { of Jerk }\end{array}$ \\
\hline $\mathrm{JE}\left(\mathrm{cm} / \mathrm{s}^{3}\right)^{2}$ & Jerk Energy & $\begin{array}{c}\text { Natural logarithm of the sum of the squares of the sampled average } \\
\text { jerk over the entire jerk time history }\end{array}$ \\
\hline
\end{tabular}

a.yaseen@uod.ac, ezgeen@uod.ac, yaman.alkamaki@uod.ac 


\subsection{Structural response of considered buildings in the current study}

The response of a construction influenced by an earthquake can be assessed using a nonlinear dynamic analysis. This technique employs the direct mathematical interaction of the differential expressions of motion by taking the elastoplastic deformation of the structural members. Such nonlinear dynamic analyses are also known as time-history analyses. To create the 3D models and undertake the required non-linear dynamic analyses, the general-purpose finite element analysis (FEA) program ETABS 2016 (Computers and Structures, Inc., 2016) was utilized in this study. The software is able to assess the nonlinear behavior of frames under static or dynamic loadings, taking into account both material and geometric nonlinearities. A key input for such an analysis, dynamic analysis, is a ground motion accelerogram that is suitable for the seismic hazard analysis of the nominated area. A number of ground-motion time histories are required by ETABS software to effectively conduct the time history analyses and predict the structural behavior of the buildings.

Six models of regular and irregular reinforced concrete (RC) frame buildings of different numbers of stories (Table 3 ) considered in this study. All buildings have a $3 \mathrm{~m}$ floor-to-floor height and fixed at their supports. Buildings have three spans in the $\mathrm{X}$ and $\mathrm{Y}$ directions (square plan of $15 \mathrm{~m} \times 15 \mathrm{~m}$ ). The evaluated $\mathrm{RC}$ frame buildings are designed in such a way that they are only able to resist gravity loads (Live load of $2 \mathrm{kN} / \mathrm{m}^{2}$ and deal load of 2 $\mathrm{kN} / \mathrm{m}^{2}$ (excluding the self-weight)), which is the model widely used in larger cities in the Kurdistan region of Iraq. The slabs of the structures are reflected to be $0.15 \mathrm{~m}$ thick. Figures 2 to 4 show a two- and threedimensional view of the nominated RC building frames. Sectional dimensions of columns and beams with the number of longitudinal reinforcement bars are also represented in Table 3.

In ETABS, a nonlinear time history analysis can be conducted utilizing either user-defined nonlinear hinge properties, default hinge properties, or automated hinge properties. Automated hinge properties are determined automatically from the frame element material and section properties according to ASCE 41-17 (ASCE, 2017) criteria. Hinges are assigned at both ends of each element, beams, and columns. The concrete moment (M) hinge type and the concrete axial force-biaxial moment (P-M-M) hinge type are respectively used to account for the behavior of hinges formed in the beams and columns. The material characteristics assigned to the frame element are used to predict the plastic response of the hinges, while the elastic response of the frame elements is calculated by the frame sections assigned to the elements. Hinges are assigned to the $5 \%$ and $95 \%$ of the length of beams and columns (at their ends). Default values given by ETABS software were considered for nonlinear parameters and other required properties for definition of nonlinear hinges. Time histories were applied in $\mathrm{X}$ direction to each model and structural response in terms of top displacement (in $\mathrm{X}$ - direction) then were recorded.

Table (3): Detail of the considered buildings in the current study

\begin{tabular}{|c|c|c|c|c|c|c|c|c|}
\hline $\begin{array}{l}\text { Type of } \\
\text { Structu } \\
\text { re }\end{array}$ & $\begin{array}{c}\text { Numb } \\
\text { er of } \\
\text { storey } \\
\text { s } \\
\end{array}$ & $\begin{array}{l}\text { Irregularity } \\
\text { in shape }\end{array}$ & $\begin{array}{c}\text { Colum } \\
\text { n } \\
\text { sectio } \\
\text { n mm }\end{array}$ & $\begin{array}{l}\text { Column } \\
\text { Reinforceme } \\
\text { nt } \mathrm{mm}^{2} \text { * }\end{array}$ & $\begin{array}{l}\text { Beam } \\
\text { section } \\
\text { mm }\end{array}$ & $\begin{array}{l}\text { Beam } \\
\text { Reinforce } \\
\text { ment } \mathrm{mm}^{2}\end{array}$ & $\begin{array}{l}\text { Compressive } \\
\text { strength of } \\
\text { Concrete } \\
\text { MPa }\end{array}$ & $\begin{array}{c}\text { Yield } \\
\text { strength of } \\
\text { Steel } \\
\mathrm{MPa} \\
\end{array}$ \\
\hline URM & 2 & \multicolumn{7}{|c|}{ 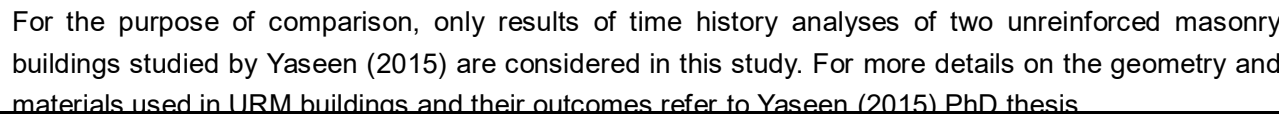 } \\
\hline \multirow{7}{*}{$\begin{array}{l}\text { Reinfor } \\
\text { ced } \\
\text { Concret } \\
\text { e }\end{array}$} & 3 & Regular & $400 \times 4$ & 1600 (8Ф16 & \multirow{7}{*}{$\begin{array}{c}400 \times 40 \\
0\end{array}$} & \multirow{7}{*}{$\begin{array}{c}1200 \\
(6 \Phi 16 \mathrm{~mm} \\
\text { at middle } \\
\text { and } \\
\text { supports) }\end{array}$} & 21 & 414 \\
\hline & 5 & & $500 \times 5$ & 2500 & & & 21 & 414 \\
\hline & 7 & & $500 \times 5$ & 3800 & & & 28 & 414 \\
\hline & 10 & & $500 \times 5$ & 3800 & & & 28 & 414 \\
\hline & 13 & & $600 \times 6$ & 3800 & & & 28 & 414 \\
\hline & 15 & & $600 \times 6$ & 3800 & & & 28 & 414 \\
\hline & 3 & Irregular- & $400 \times 4$ & 1600 (8Ф16 & & & 21 & 414 \\
\hline
\end{tabular}

a.yaseen@uod.ac, ezgeen@uod.ac, yaman.alkamaki@uod.ac 
Journal of University of Duhok, Vol. 23, No.2 (Pure and Eng. Sciences), Pp 254-277, 2020 (Special Issue)

$3^{\text {rd }}$ international conference on recent innovations in engineering (ICRIE) Duhok, September 9-10-2020

\begin{tabular}{|c|c|c|c|c|c|}
\hline 5 & \multirow[t]{3}{*}{ Plus shape } & $500 \times 5$ & 2500 & 21 & 414 \\
\hline 10 & & $500 \times 5$ & 3800 & 28 & 414 \\
\hline 15 & & $600 \times 6$ & 3800 & 28 & 414 \\
\hline 3 & \multirow{4}{*}{$\begin{array}{l}\text { Irregular- } \\
\text { L shape }\end{array}$} & $400 \times 4$ & $1600(8 \Phi 16$ & 21 & 414 \\
\hline 5 & & $500 \times 5$ & 2500 & 21 & 414 \\
\hline 10 & & $500 \times 5$ & 3800 & 28 & 414 \\
\hline 15 & & $600 \times 6$ & 3800 & 28 & 414 \\
\hline 3 & \multirow{4}{*}{$\begin{array}{l}\text { Irregular- } \\
\text { I shape }\end{array}$} & $400 \times 4$ & 1600 & 21 & 414 \\
\hline 5 & & $500 \times 5$ & 2500 & 21 & 414 \\
\hline 10 & & $500 \times 5$ & 3800 & 28 & 414 \\
\hline 15 & & $600 \times 6$ & 3800 & 28 & 414 \\
\hline 3 & \multirow{4}{*}{$\begin{array}{l}\text { Irregular- } \\
\text { Set Back }{ }^{1}\end{array}$} & $400 \times 4$ & $1600(8 \Phi 16$ & 21 & 414 \\
\hline 5 & & $500 \times 5$ & 2500 & 21 & 414 \\
\hline 10 & & $500 \times 5$ & 3800 & 28 & 414 \\
\hline 15 & & $600 \times 6$ & 3800 & 28 & 414 \\
\hline 3 & \multirow{4}{*}{$\begin{array}{l}\text { Irregular- } \\
\text { Set Back }^{2}\end{array}$} & $400 \times 4$ & $1600(8 \Phi 16$ & 21 & 414 \\
\hline 5 & & $500 \times 5$ & 2500 & 21 & 414 \\
\hline 10 & & $500 \times 5$ & 3800 & 28 & 414 \\
\hline 15 & & $600 \times 6$ & 3800 & 28 & 414 \\
\hline
\end{tabular}

* For stirrups $\Phi 10 \mathrm{~mm}$ at $200 \mathrm{~mm}$ used.

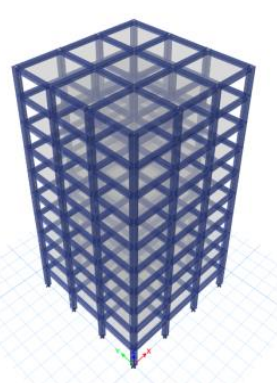

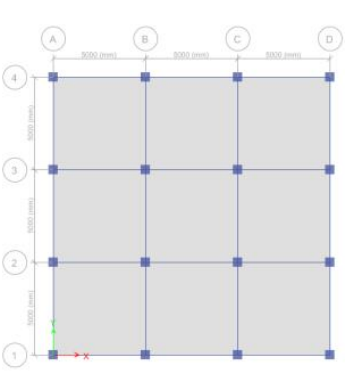

(a)

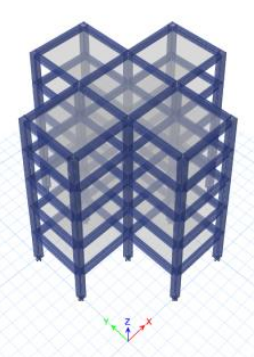

(b)

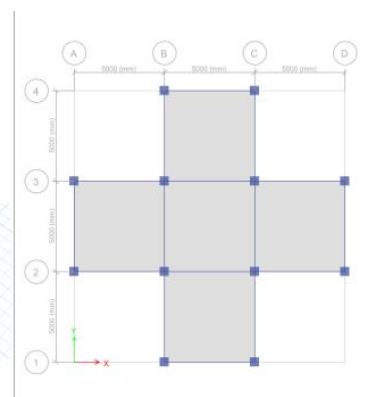

Figure 2 Typical models of (a) regular RC frame (b) Irregular plus shape RC frame

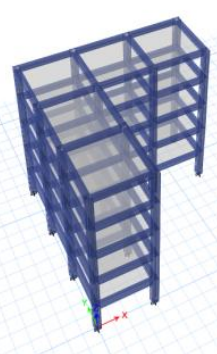

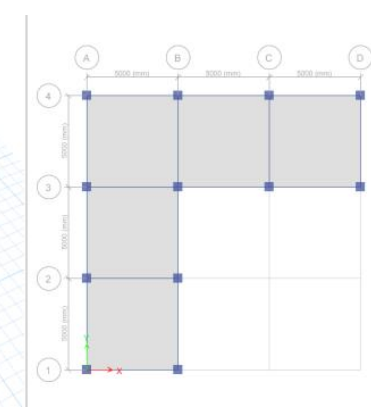

(a)

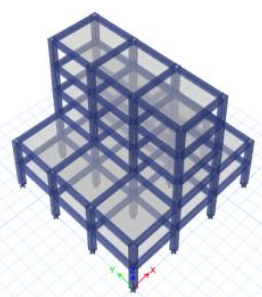

(b)

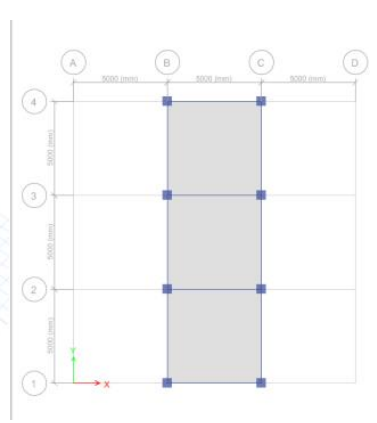

(b)

Fig. (3): Typical models of (a) Irregular L shape RC frame (b) Irregular I shape RC frame

a.yaseen@uod.ac, mezgeen@uod.ac, yaman.alkamaki@uod.ac

${ }^{1}$ Corresponding author: College of Engineering, University of Duhok, Kurdistan Region, Iraq 


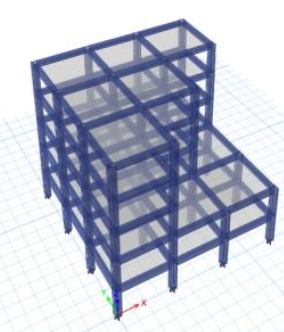

(a)

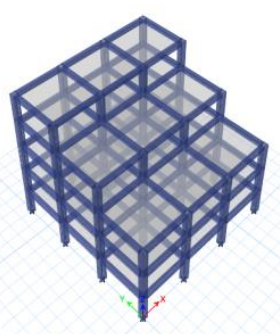

(b)

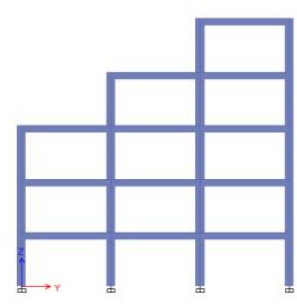

Fig. (4): Typical models of (a) Irregular set back ${ }^{1}$ shape RC frame (b) Irregular set back ${ }^{2}$ shape RC frame

\subsection{Ground motion records}

Despite the high variability in ground motions, it is desirable to choice as few records as possible for these types of analyses. This is mostly due to the nonlinear modeling and dynamic analysis are computationally onerous and highly time-consuming. Although the suitable number of records is still a matter for debate, in practice, it is typical to use seven motions according to EC8 (CEN, 2003) and ASCE/SEI-7 (ASCE, 2010) or eleven ground motions as specified by ATC-58 (2011). The average behavior of the structure is the outcome of the analysis if the aforementioned number of ground motions takes as input to the analysis. Shome et al. (1998) also affirmed that for a medium-rise building, ten to twenty records are adequate to evaluate its seismic demand with great confidence. Hence, in this investigation, and to minimize the bias due to variability in ground motions, two suites of selected seven, and twenty-seven ground motions are chosen in such a way as to be compatible with the seismic characteristics of the Kurdistan Region of Iraq. Nominated motion records were suggested by Yaseen (2015) for Kurdistan Region of Iraq and were derived from PEER Next Generation Attenuation NGA Strong Motion Database (available

at http://peer.berkeley.edu/assets/NGA_Flatfile.xls) . Tables 4 and 5 present specifications of the selected ground motions.

Table (4): Specifications of a suite of seven ground motions

\begin{tabular}{cccccc}
\hline No. & $\begin{array}{c}\text { NGA Record } \\
\text { Number }\end{array}$ & Earthquake Name & $\begin{array}{c}\text { Earthquake } \\
\text { Moment Magnitude }\end{array}$ & $\begin{array}{c}\text { Epicentral } \\
\text { Distance(km) }\end{array}$ & PGA(g) \\
\hline 1 & 126 & Gazli, USSR & 6.8 & 12.82 & 0.6 \\
\hline 2 & 143 & Tabas, Iran & 7.35 & 55.24 & 0.84 \\
\hline 3 & 802 & Loma Prieta & 6.93 & 27.23 & 0.51 \\
\hline 4 & 821 & Erzican, Turkey & 6.69 & 8.97 & 0.5 \\
\hline 5 & 828 & Cape Mendocino & 7.01 & 4.51 & 0.59 \\
\hline 6 & 1086 & Northridge-01 & 6.69 & 16.77 & 0.6 \\
\hline 7 & 1602 & Duzce, Turkey & 7.14 & 41.27 & 0.73 \\
\hline
\end{tabular}

Table 5 Specifications of a suite of twenty-seven ground motions

\begin{tabular}{|c|c|c|c|c|c|c|c|c|c|c|c|}
\hline No. & $\begin{array}{c}\text { NGA } \\
\text { Record } \\
\text { Number }\end{array}$ & $\begin{array}{c}\text { Earthquake } \\
\text { Name }\end{array}$ & $\begin{array}{c}\text { Earthquake } \\
\text { Moment } \\
\text { Magnitude }\end{array}$ & $\begin{array}{c}\text { Epicentral } \\
\text { Distance(km) }\end{array}$ & PGA(g) & No. & $\begin{array}{c}\text { NGA } \\
\text { Record } \\
\text { Number }\end{array}$ & $\begin{array}{c}\text { Earthquake } \\
\text { Name }\end{array}$ & $\begin{array}{c}\text { Earthquake } \\
\text { Moment } \\
\text { Magnitude }\end{array}$ & $\begin{array}{c}\text { Epicentral } \\
\text { Distance }(\mathbf{k m})\end{array}$ & $P G A(g)$ \\
\hline 1 & 126 & Gazli,USSR & 6.8 & 12.82 & 0.6 & 15 & 983 & Northridge- & 6.69 & 13 & 0.57 \\
\hline 2 & 143 & Tabas, Iran & 7.35 & 55.24 & 0.84 & 16 & 1004 & Northridge- & 6.69 & 8.48 & 0.75 \\
\hline 4 & 179 & $\begin{array}{l}\text { Imperial } \\
\text { Valley-06 }\end{array}$ & 6.53 & 27.13 & 0.36 & 18 & 1044 & $\begin{array}{c}\text { Northridge- } \\
01\end{array}$ & 6.69 & 20.27 & 0.58 \\
\hline
\end{tabular}

a.yaseen@uod.ac, mezgeen@uod.ac, yaman.alkamaki@uod.ac 
Journal of University of Duhok, Vol. 23, No.2 (Pure and Eng. Sciences), Pp 254-277, 2020 (Special Issue)

$3^{\text {rd }}$ international conference on recent innovations in engineering (ICRIE) Duhok, September 9-10-2020

\begin{tabular}{|c|c|c|c|c|c|c|c|c|c|c|c|}
\hline 6 & 184 & $\begin{array}{l}\text { Imperial } \\
\text { Valley-06 }\end{array}$ & 6.53 & 27.23 & 0.35 & 20 & 1085 & $\begin{array}{c}\text { Northridge- } \\
01\end{array}$ & 6.69 & 13.6 & 0.83 \\
\hline 7 & 568 & San & 5.8 & 7.93 & 0.88 & 21 & 1086 & Northridge- & 6.69 & 16.77 & 0.6 \\
\hline 8 & 802 & Loma Prieta & 6.93 & 27.23 & 0.51 & 22 & 1119 & Kobe, & 6.9 & 38.6 & 0.69 \\
\hline 10 & 825 & $\begin{array}{c}\text { Cape } \\
\text { Mendocino }\end{array}$ & 7.01 & 10.36 & 1.5 & 24 & 1507 & $\begin{array}{l}\text { Chi-Chi, } \\
\text { Taiwan }\end{array}$ & 7.62 & 15.42 & 0.57 \\
\hline 11 & 828 & $\begin{array}{c}\text { Cape } \\
\text { Mendocino }\end{array}$ & 7.01 & 4.51 & 0.59 & 25 & 1508 & $\begin{array}{l}\text { Chi-Chi, } \\
\text { Taiwan }\end{array}$ & 7.62 & 21.42 & 0.49 \\
\hline 14 & 963 & Northridge- & 6.69 & 40.68 & 0.57 & & & & & & \\
\hline
\end{tabular}

\subsection{Machine learning process}

As noted previously, the purpose of this study is to find an IM (or IMs) that correlated better with the response of buildings. Due to the number of ground motions being considered and the number of IMs under investigation, the process of determining the level of correlation for each of the IMs is a complex exercise. Machine learning offers tools by which large numbers of data can be automatically analyzed to evaluate such associations. Two methodologies that enable standard machine learning algorithms to be applied to large databases are feature selection and sampling. Both reduce the size of the database-feature selection by identifying the most salient features in the data; sampling by recognizing demonstrative examples (John and Langley,1996). This paper emphasis on feature selection-a process that can benefit learning algorithms regardless of the number of data accessible to learn from. The profits of feature selection for learning can comprise a reduction in the number of data required to complete learning, enhanced predictive accuracy, learned information that is more compact and easily understood, and reduced execution time (Langley and Simon,1995).

Current key choice approaches for machine learning characteristically fall into two broad classes those which assess the worth of features using the learning algorithm that is to eventually be applied to the data, and those which evaluate the worth of features by using heuristics based on general characteristics of the data. The former is referred to as wrappers and the latter filters (Kohavi,1995; Kohavi and John,1996). The wrapper is one of the simplest feature selectors conceptually (though not computationally) and has been found to generally out-perform filter methods (John,1994; Caruana and Freitag, 1994). Wrappers are generally considered to be superior to filters as they are tuned to the specific interaction between a learning algorithm and its training data and stand the best chance of finding the "optimal" feature subset. The feature selector is simple and fast to execute. It reduces inappropriate and redundant data and, in numerous circumstances, enhances the effectiveness of learning algorithms. Studies has proven that no single learning method is obviously superior in all cases, and in fact, various learning algorithms often produce similar outcomes (Langley and Simon,1995). Accordingly, in this study, a two-stage technique (subset merging technique) for feature selection is applied to reduce the bias caused by using different types of machine learning algorithms. WEKA workbench (Holmes et al.,1994) was used for that purpose.

A good feature subset is one that contains features (Ground-motion IMs) greatly related with (predictive of) the class (here the response of the buildings to the ground motion time history, yet uncorrelated with (not predictive of) each other. Evaluation of the above hypothesis is accomplished by creating a feature selection algorithm that evaluates the worth of feature sets. Wrapper subset evaluator (Wrappersubseteval), as an attribute selection

a.yaseen@uod.ac, mezgeen@uod.ac, yaman.alkamaki@uod.ac

${ }^{1}$ Corresponding author: College of Engineering, University of Duhok, Kurdistan Region, Iraq 
evaluator, is a component of the WEKA workbench (Holmes et al.,1994), which itself is part of ongoing research at the University of Waikato to produce a high-quality process model for machine learning. Wrappersubseteval evaluates attribute sets by using a learning scheme.

Accuracy estimation for the wrapper is achieved through 5-fold cross validation (obtained by trial and error procedure) of the 'training' set. Different types of Classifiers (machine learning algorithms) have been used for estimating the accuracy of subsets and they are: M5P (Implements the M5' model tree algorithm.); Random Tree (Class that considers $\mathrm{k}$ randomly chosen attributes at each node but performs no pruning.); Linear Regression (an algorithm that uses linear regression for prediction and which. uses the Akaike criterion for model selection and is able to deal with weighted instances. Attribute selection is carried out by using M5's method (step through the attributes removing the one with the smallest standardized coefficient until no improvement is observed in the estimate of the error given by the Akaike information criterion)); Gaussian processes (implements Gaussian processes for regression without hyperparameter-tuning. To make choosing an appropriate noise level easier, this implementation applies normalization/standardization to the target attribute as well as the other attributes); MultilayerPerceptron (an algorithm that uses back-propagation to learn a multi-layer perceptron to classify instances. The network can be built by hand or set up using a simple heuristic. The network parameters can also be monitored and modified during training time. The nodes in this network are all sigmoid (except for when the class is numeric, in which case the output nodes become unthresholded linear units). Each represents a different approach to learning. These algorithms are well known in the machine learning community and have proved popular in practice (Holmes et al.,1994).

The following section thoroughly details the outcomes of the study and discusses the significance of the results.

\section{RESULTS AND DISCUSSION}

Twenty-seven ground motion time histories were applied to six models of regular and irregular reinforced concrete frames having different number of stories. In total, 702 runs of time history analyses were undertaken with the top displacement of each model recorded.

Machine learning applied to the obtained data using WEKA workbench. A forward best first search is used with all variations of wrapper subset evaluation; the forward best first search evaluated fewer subsets than backward elimination. Wrappers evaluate feature subsets by statistical estimation of their accuracy with respect to a learning algorithm. The measure used to evaluate the performance of attribute combinations was root mean square error (RMSE). A RMSE of 0.01 thresholds (default value given by WEKA) has been applied.

In a typical supervised machine learning task, data is represented as a table of examples or instances. Each instance is described by a fixed number of measurements, or features, along with a label that denotes its class. Features (sometimes called attributes) are typically one of two types: nominal (values are members of an unordered set), or numeric (values are real numbers). Each instance is a ground motion time history described in terms of the (numeric) attributes PGA, PGJ, and etc, along with the class label which indicates the response of the buildings in terms of top displacement in $\mathrm{X}$ direction. Tables A1 to A5 present the results of time history analyses of models along with showing all 33 ground-motion IMs that are defined and calculated for the different ground motion time histories used in this study. Because of a large amount of data it's not possible to present all of the results graphically, so only the top displacement time history for the earthquake NGA record number 126 (Gazli,USSR earthquake in 1976, Turkey) applied to five story regular RC frame is shown in Figure 5 in addition to its acceleration and jerk time histories. 

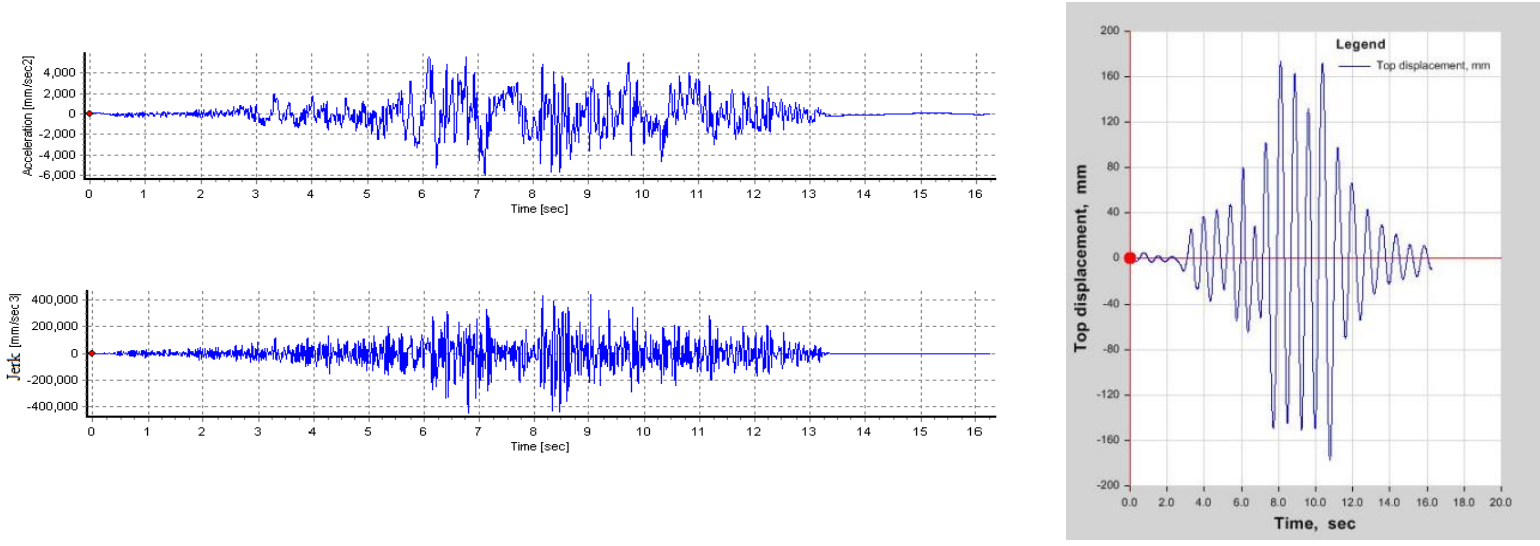

Fig.(5): Acceleration and jerk time histories (left) and top displacement time history for 5 story regular RC frame (right) of earthquake NGA record number 126 (Gazli,USSR earthquake in 1976, Turkey)

Different subsets of features have been selected by using different learning schemes available in Wrappersubseteval within WEKA. Subsets with the higher merit of the accuracy are shown in the Tables 6 and A6. In many cases the number of features is reduced by more than $90 \%$. It's clearly shown in Tables 6 and A6 that thirty-three features (IMs) have been reduced to subsets contain different numbers of features varying from 1 to 6 features according to the learning scheme that gave the higher merit. It's of great importance to mention that different types of machine learning algorithms mentioned in Section 2.4 were examined and the one which give the highest merit was selected in order to choose the best subset of features. Hence it's not study's aim to undertake a comparison among different available learning algorithms and investigate their performance.

Table (6): Subsets of ground-motion IMs obtained from the first stage of feature selection process for the seven earthquake record dataset

\begin{tabular}{|c|c|c|c|c|}
\hline Buildings & Three Story Regular & Five Story Regular & Ten Story Regular & Fifteen Story Regular \\
\hline \multirow{4}{*}{$\begin{array}{l}\text { Subset of ground } \\
\text { motion IMs }\end{array}$} & $\mathrm{Sj}$, avg $\left(\mathrm{cm} / \mathrm{s}^{3}\right)$ & $\mathrm{Tb}(2000)(\mathrm{s})$ & $\mathrm{JE}\left(\mathrm{cm} / \mathrm{s}^{3}\right)^{2}$ & PGV $(\mathrm{cm} / \mathrm{s})$ \\
\hline & PGV $(\mathrm{cm} / \mathrm{s})$ & & $\mathrm{ASI}(\mathrm{m} / \mathrm{s})$ & \\
\hline & $\operatorname{SED}\left(\mathrm{cm}^{2} / \mathrm{s}\right)$ & & $\mathrm{IH}(\mathrm{cm})$ & \\
\hline & & & Sa, ave. $\left(\mathrm{cm} / \mathrm{s}^{2}\right)$ & \\
\hline Merit & 31.05 & 68 & 41.37 & 214.76 \\
\hline Learning algorithm & LinearRegression & M5P & LinearRegression & M5P \\
\hline Buildings & $\begin{array}{c}\text { Three Story Irregular } \\
\text { SetBack }^{1}\end{array}$ & $\begin{array}{l}\text { Five Story Irregular } \\
\text { SetBack }^{1}\end{array}$ & $\begin{array}{c}\text { Ten Story Irregular } \\
\text { SetBack }^{1}\end{array}$ & $\begin{array}{c}\text { Fifteen Story Irregular } \\
\text { SetBack }^{1}\end{array}$ \\
\hline \multirow{2}{*}{$\begin{array}{l}\text { Subset of ground } \\
\text { motion IMs }\end{array}$} & $\operatorname{EDA}\left(\mathrm{m} / \mathrm{s}^{2}\right)$ & $\mathrm{Tb}(2000)(\mathrm{s})$ & $\mathrm{SMV}(\mathrm{cm} / \mathrm{s})$ & PGV $(\mathrm{cm} / \mathrm{s})$ \\
\hline & & & Damage index & \\
\hline Merit & 34 & 36 & 66.86 & 219.23 \\
\hline Learning algorithm & M5P & LinearRegression & MultilayerPerceptron & M5P \\
\hline Buildings & $\begin{array}{c}\text { Three Story Irregular } \\
\text { SetBack }^{2}\end{array}$ & $\begin{array}{c}\text { Five Story Irregular } \\
\text { SetBack }^{2} \\
\end{array}$ & $\begin{array}{c}\text { Ten Story Irregular } \\
\text { SetBack }^{2}\end{array}$ & $\begin{array}{c}\text { Fifteen Story Irregular } \\
\text { SetBack }^{2}\end{array}$ \\
\hline \multirow{4}{*}{$\begin{array}{l}\text { Subset of ground } \\
\text { motion IMs }\end{array}$} & VSI (cm) & Time of Max. Jerk (s) & $\mathrm{IH}(\mathrm{cm})$ & $\mathrm{CAV}(\mathrm{cm} / \mathrm{s})$ \\
\hline & & JRMS $\left(\mathrm{cm} / \mathrm{s}^{3}\right)$ & & $\mathrm{IH}(\mathrm{cm})$ \\
\hline & & $\operatorname{Tm}(\mathrm{s})$ & & $\mathrm{SMV}(\mathrm{cm} / \mathrm{s})$ \\
\hline & & IP Index & & Damage index \\
\hline Merit & 35.8 & 40 & 74.5 & 114.37 \\
\hline
\end{tabular}

a.yaseen@uod.ac, mezgeen@uod.ac, yaman.alkamaki@uod.ac

${ }^{1}$ Corresponding author: College of Engineering, University of Duhok, Kurdistan Region, Iraq 
Journal of University of Duhok, Vol. 23, No.2 (Pure and Eng. Sciences), Pp 254-277, 2020 (Special Issue)

$3^{\text {rd }}$ international conference on recent innovations in engineering (ICRIE) Duhok, September 9-10-2020

\begin{tabular}{|c|c|c|c|c|}
\hline Learning algorithm & M5P & LinearRegression & Multilayer Perceptron & Random Tree \\
\hline Buildings & $\begin{array}{c}\text { Three Story Irregular } \\
\text { I shape }\end{array}$ & $\begin{array}{c}\text { Five Story Irregular } \\
\text { I shape }\end{array}$ & $\begin{array}{c}\text { Ten Story Irregular } \\
\text { I shape }\end{array}$ & $\begin{array}{c}\text { Fifteen Story Irregular } \\
\text { I shape }\end{array}$ \\
\hline \multirow{6}{*}{$\begin{array}{l}\text { Subset of ground } \\
\text { motion IMs }\end{array}$} & Time of Max. Jerk (s) & Sj,avg $\left(\mathrm{cm} / \mathrm{s}^{3}\right)$ & $\mathrm{JSI}\left(\mathrm{cm} / \mathrm{s}^{2}\right)$ & $\operatorname{ARMS}\left(\mathrm{m} / \mathrm{s}^{2}\right)$ \\
\hline & & $\mathrm{IH}(\mathrm{cm})$ & VRMS $(\mathrm{cm} / \mathrm{s})$ & $\operatorname{SED}\left(\mathrm{cm}^{2} / \mathrm{s}\right)$ \\
\hline & & $\mathrm{SMV}(\mathrm{cm} / \mathrm{s})$ & $\operatorname{SED}\left(\mathrm{cm}^{2} / \mathrm{s}\right)$ & $\operatorname{SMA}\left(\mathrm{m} / \mathrm{s}^{2}\right)$ \\
\hline & & A95 $\left(\mathrm{m} / \mathrm{s}^{2}\right)$ & VSI (cm) & Damage index \\
\hline & & $\mathrm{TP}(\mathrm{s})$ & & \\
\hline & & Sa,ave. $\left(\mathrm{cm} / \mathrm{s}^{2}\right)$ & & \\
\hline Merit & 27 & 39.54 & 63.72 & 136 \\
\hline Learning algorithm & M5P & LinearRegression & Random Tree & Random Tree \\
\hline Buildings & $\begin{array}{c}\text { Three Story Irregular } \\
\text { L shape }\end{array}$ & $\begin{array}{c}\text { Five Story Irregular } \\
\text { L shape }\end{array}$ & $\begin{array}{c}\text { Ten Story Irregular } \\
\text { L shape }\end{array}$ & $\begin{array}{c}\text { Fifteen Story Irregular } \\
\text { L shape }\end{array}$ \\
\hline \multirow{2}{*}{$\begin{array}{l}\text { Subset of ground } \\
\text { motion IMs }\end{array}$} & $\mathrm{VSI}(\mathrm{cm})$ & $\mathrm{Tb}(2000)(\mathrm{s})$ & PGV $(\mathrm{cm} / \mathrm{s})$ & $\mathrm{IH}(\mathrm{cm})$ \\
\hline & & & & $\mathrm{TP}(\mathrm{s})$ \\
\hline Merit & 31.2 & 74 & 100.86 & 146 \\
\hline Learning algorithm & M5P & M5P & M5P & Random Tree \\
\hline Buildings & $\begin{array}{c}\text { Three Story Irregular } \\
\text { Plus shape }\end{array}$ & $\begin{array}{c}\text { Five Story Irregular } \\
\text { Plus shape } \\
\end{array}$ & $\begin{array}{c}\text { Ten Story Irregular } \\
\text { Plus shape } \\
\end{array}$ & $\begin{array}{c}\text { Fifteen Story Irregular } \\
\text { Plus shape }\end{array}$ \\
\hline \multirow{2}{*}{$\begin{array}{l}\text { Subset of ground } \\
\text { motion IMs }\end{array}$} & VSI (cm) & $\mathrm{Tb}(2000)(\mathrm{s})$ & PGV $(\mathrm{cm} / \mathrm{s})$ & JRMS $\left(\mathrm{cm} / \mathrm{s}^{3}\right)$ \\
\hline & & & & $\mathrm{PGV}(\mathrm{cm} / \mathrm{s})$ \\
\hline Merit & 31.1 & 68.85 & 87.76 & 219.27 \\
\hline Learning algorithm & M5P & M5P & M5P & M5P \\
\hline Buildings & One story URM & Two story URM & & \\
\hline \multirow{6}{*}{$\begin{array}{l}\text { Subset of ground } \\
\text { motion IMs }\end{array}$} & $\mathrm{SMJ}\left(\mathrm{cm} / \mathrm{s}^{3}\right)$ & $\mathrm{JSI}\left(\mathrm{cm} / \mathrm{s}^{2}\right)$ & & \\
\hline & PGD (cm) & J95 parameter $\left(\mathrm{cm} / \mathrm{s}^{3}\right)$ & & \\
\hline & $\operatorname{SED}\left(\mathrm{cm}^{2} / \mathrm{s}\right)$ & DRMS (cm) & & \\
\hline & $\operatorname{EDA}\left(\mathrm{m} / \mathrm{s}^{2}\right)$ & $\mathrm{ASI}(\mathrm{m} / \mathrm{s})$ & & \\
\hline & $\operatorname{Tm}(\mathrm{s})$ & $\operatorname{Tm}(\mathrm{s})$ & & \\
\hline & & IP Index & & \\
\hline Merit & 2.39 & 8.56 & & \\
\hline Learning algorithm & GaussianProcesses & Random Tree & & \\
\hline
\end{tabular}

From the results shown in Tables 6 and A6, it is obvious that jerk based parameters contribute greatly the accuracy for subsets that have been selected within each sets of data. Furthermore, it's clear that the selection of jerk based parameters influenced by the number of the number of storeys. For buildings having less than 10 storeys, it seems that the jerk-based parameters can play a positive role in relating the seismic demand (ground motion time history) to the building capacity (structural response to the seismic action). However, for a specific number of storeys, there are several subsets that contain a different number of parameters depending on the learning schemes used. To minimize that variance and in the second stage of the machine learning process the best subsets corresponding to the number of storeys of different tested buildings are merged together and the merit of this new composite subset is recalculated. If the merit is within $10 \%$ of the minimum merit of the subsets obtained in the first stage, the composite is accepted. The results of this stage of analysis are shown in Tables 7, 8, A7 and A8.

Merging feature subsets has made the result

a.yaseen@uod.ac, mezgeen@uod.ac, yaman.alkamaki@uod.ac

${ }^{1}$ Corresponding author: College of Engineering, University of Duhok, Kurdistan Region, Iraq 
for the two sets of ground motion records ( 7 and 27 records) better. It is clear that there are many subsets that contain less numbers of features with a merit equal or close to the highest merit of those subsets obtained in the first stage. Considering the number of features (IMs) selected, improvements in performance can clearly be seen on the $3,5,10$, and 15 story RC frame datasets for both of 7 and 27 records between Wrappersubseteval with merged subsets and Wrappersubseteval without merged subsets.

For almost all of the determined subsets of significant IMs for the three and five storey RC frame buildings, jerk based parameters are included. Hence, their contribution in gaining higher predictive accuracy of the results (top displacement response of buildings) can't be ignored; especially for those buildings having less than 10 storeys. This becomes much clearer when the results of a seven and thirteen story regular RC frame under application of the 27 records was also added to the other results as shown in Table A6.

To investigate the importance of jerk-based parameters as IM for different type of structures, the results of time history analysis for two URM buildings of Yaseen (2015) thesis were also used here. Top displacements in $\mathrm{x}$ direction under the application of the same earthquake records which used here in this study were selected and machine learning applied to data. As shown in Table 6, it can be concluded that with respect to the URM buildings, jerk based parameters lost their importance with comparison to the other considered seismic ground motion parameters since the lower merit was recorded for subsets selected in both sets of 7 and 27 records compared to the RC frame buildings. Thus, it can be concluded that jerk based parameters have less correlation to buildings having a more non-linear high response. On other hand, jerk based- parameters correlate better with short period structures as found for the less than 10 storeys RC frame buildings. This can be discussed as following: if structures have large deformation capability, earthquake energy is absorbed by nonlinear and inelastic behavior; however, for structures with small deformation capability, structural failure may be triggered due to strong ground motion. Hence, for tall and long-period structures that have higher vibration modes, the jerk-based parameter may not be a good choice as an IM to correlate with structural response under earthquakes. The finding of this study agrees well with findings of HE et al. (2011) and He et al. (2015) studies as mentioned in section 1. Furthermore, similarly to other studied mentioned in section 2.4 (e.gLangley and Simon,1995) and as can be seen from Tables 6-8 and A6-A8, no single learning algorithm has been found to be superior to all of the others for the problem discussed in this study.

To this end it should be mentioned that it was out of scope of this study to consider the influence of factors such as ductility, soilstructure interaction, infill walls, distribution of the masses in the building, distance of the buildings from faults with focal depths and etc. Authors tried to perform a typical study in order to find the possibility of using jerk- based parameters as ground -motion IM considering the most important factors affecting such studies and they are the method of structural analysis, type of ground motion and their selection in addition to the number of ground motions and statistical method of data postprocess. Future studies always required to enhance and improve the findings of such type of studies considering all of the aforementioned factors.

Table (7): Subsets of ground-motion IMs obtained for three and five story RC frame buildings from the second stage of feature selection process (sub-merging scheme) (Seven earthquake record dataset)

\begin{tabular}{|c|c|c|c|c|c|c|c|}
\hline $\begin{array}{l}\text { Three story RC } \\
\text { frame }\end{array}$ & $\begin{array}{c}\text { Subset of } \\
\text { ground } \\
\text { motion IMs }\end{array}$ & Merit & $\begin{array}{l}\text { Learning } \\
\text { algorithm }\end{array}$ & Five story RC frame & $\begin{array}{c}\text { Subset of } \\
\text { ground } \\
\text { motion IMs }\end{array}$ & Merit & $\begin{array}{l}\text { Learning } \\
\text { algorithm }\end{array}$ \\
\hline Regular & $\mathrm{Sj}, \operatorname{avg}\left(\mathrm{cm} / \mathrm{s}^{3}\right)$ & 31 & M5P & Regular & $\operatorname{Tb}(2000)(\mathrm{s})$ & 68.32 & M5P \\
\hline Irregular SetBack ${ }^{1}$ & $\operatorname{EDA}\left(\mathrm{m} / \mathrm{s}^{2}\right)$ & 34.6 & M5P & \multirow[t]{4}{*}{ Irregular SetBack ${ }^{1}$} & $\mathrm{~Tb}(2000)(\mathrm{s})$ & \multirow[t]{4}{*}{46} & \multirow{4}{*}{$\begin{array}{c}\text { Random } \\
\text { Tree }\end{array}$} \\
\hline Irregular SetBack ${ }^{2}$ & VSI (cm) & 35.8 & M5P & & $\mathrm{IH}(\mathrm{cm})$ & & \\
\hline Irregular I shape & $\begin{array}{c}\text { Time of Max. } \\
\text { Jerk (s) }\end{array}$ & 27 & M5P & & $\mathrm{Tm}(\mathrm{s})$ & & \\
\hline Irregular L shape & $\mathrm{Sj}$, avg $\left(\mathrm{cm} / \mathrm{s}^{3}\right)$ & 31.45 & linear & & Damage & & \\
\hline IrregularPlusshape & VSI (cm) & 31 & M5P & Irregular SetBack ${ }^{2}$ & Time of Max. & 40 & linear \\
\hline
\end{tabular}

a.yaseen@uod.ac, mezgeen@uod.ac, yaman.alkamaki@uod.ac ${ }^{1}$ Corresponding author: College of Engineering, University of Duhok, Kurdistan Region, Iraq 


\begin{tabular}{|c|c|c|c|c|}
\hline & & Jerk (s) & & Regression \\
\hline & & JRMS $\left(\mathrm{cm} / \mathrm{s}^{3}\right)$ & & \\
\hline & & $\operatorname{Tm}(\mathrm{s})$ & & \\
\hline & & IP Index & & \\
\hline & Irregular I shape & $\begin{array}{c}\text { Time of Max. } \\
\text { Jerk (s) }\end{array}$ & 39.6 & $\begin{array}{c}\text { Random } \\
\text { Tree }\end{array}$ \\
\hline & Irregular L shape & $\mathrm{Tb}(2000)(\mathrm{s})$ & 74.8 & M5P \\
\hline & IrregularPlusshape & $\mathrm{Tb}(2000)(\mathrm{s})$ & 68 & $\begin{array}{l}\text { Multilayer } \\
\text { Perceptron }\end{array}$ \\
\hline
\end{tabular}

Table (8): Subsets of ground motion IMs obtained for ten and fifteen story RC frame buildings from the second stage of feature selection process (sub-merging scheme) (Seven earthquake record dataset)

\begin{tabular}{|c|c|c|c|c|c|c|c|}
\hline $\begin{array}{l}\text { Ten story } \\
\text { RC frame }\end{array}$ & $\begin{array}{l}\text { Subset of } \\
\text { ground } \\
\text { motion IMs }\end{array}$ & Merit & Learning algorithm & $\begin{array}{c}\text { Fifteen } \\
\text { story RC } \\
\text { frame } \\
\end{array}$ & $\begin{array}{c}\text { Subset of } \\
\text { ground } \\
\text { motion IMs } \\
\end{array}$ & Merit & Learning algorithm \\
\hline Regular & $\operatorname{SED}\left(\mathrm{cm}^{2} / \mathrm{s}\right)$ & 66 & $\begin{array}{c}\text { GaussianProcesse } \\
\mathrm{s} \\
\end{array}$ & Regular & PGV $(\mathrm{cm} / \mathrm{s})$ & 214 & M5P \\
\hline $\begin{array}{l}\text { Irregular } \\
\text { SetBack }^{1}\end{array}$ & $\operatorname{SED}\left(\mathrm{cm}^{2} / \mathrm{s}\right)$ & 75 & $\begin{array}{c}\text { GaussianProcesse } \\
\mathrm{s} \\
\end{array}$ & $\begin{array}{l}\text { Irregular } \\
\text { SetBack }^{1} \\
\end{array}$ & PGV (cm/s) & 219 & M5P \\
\hline $\begin{array}{l}\text { Irregular } \\
\text { SetBack }^{2} \\
\end{array}$ & $\begin{array}{l}\mathrm{JE}\left(\mathrm{cm} / \mathrm{s}^{3}\right)^{2} \\
\operatorname{SED}\left(\mathrm{cm}^{2} / \mathrm{s}\right)\end{array}$ & 95 & $\begin{array}{c}\text { GaussianProcesse } \\
\mathrm{s} \\
\end{array}$ & $\begin{array}{l}\text { Irregular } \\
\text { SetBack }^{2} \\
\end{array}$ & $\begin{array}{c}\mathrm{PGV}(\mathrm{cm} / \mathrm{s}) \\
\mathrm{IH}(\mathrm{cm})\end{array}$ & $\begin{array}{c}170.1 \\
8 \\
\end{array}$ & $\begin{array}{c}\text { GaussianProcesse } \\
\text { s } \\
\end{array}$ \\
\hline $\begin{array}{c}\text { Irregular I } \\
\text { shape }\end{array}$ & $\begin{array}{c}\mathrm{JE}\left(\mathrm{cm} / \mathrm{s}^{3}\right)^{2} \\
\text { SED }\left(\mathrm{cm}^{2} / \mathrm{s}\right) \\
\begin{array}{c}\text { Damage } \\
\text { index }\end{array} \\
\end{array}$ & 73.5 & $\begin{array}{c}\text { GaussianProcesse } \\
\mathrm{s}\end{array}$ & $\begin{array}{l}\text { Irregular I } \\
\text { shape }\end{array}$ & $\begin{array}{l}\text { ARMS }\left(\mathrm{m} / \mathrm{s}^{2}\right) \\
\operatorname{SED}\left(\mathrm{cm}^{2} / \mathrm{s}\right) \\
\operatorname{SMA}\left(\mathrm{m} / \mathrm{s}^{2}\right)\end{array}$ & 136.5 & Random Tree \\
\hline $\begin{array}{l}\text { Irregular } \\
\text { L shape }\end{array}$ & $\mathrm{PGV}(\mathrm{cm} / \mathrm{s})$ & $\begin{array}{c}100.8 \\
6 \\
\end{array}$ & M5P & & $\begin{array}{c}\text { Damage } \\
\text { index }\end{array}$ & & \\
\hline $\begin{array}{l}\text { Irregular } \\
\text { plus } \\
\text { shape } \\
\end{array}$ & PGV $(\mathrm{cm} / \mathrm{s})$ & 87.7 & M5P & $\begin{array}{l}\text { Irregular L } \\
\text { shape }\end{array}$ & $\begin{array}{c}\text { JRMS } \\
\left(\mathrm{cm} / \mathrm{sec}^{3}\right) \\
\text { PGV }(\mathrm{cm} / \mathrm{s}) \\
\mathrm{IH}(\mathrm{cm}) \\
\mathrm{SMV}(\mathrm{cm} / \mathrm{s})\end{array}$ & 209 & $\begin{array}{c}\text { GaussianProcesse } \\
\text { s }\end{array}$ \\
\hline & & & & $\begin{array}{l}\text { Irregular } \\
\text { plus shape }\end{array}$ & $\begin{array}{c}\text { JRMS } \\
\left(\mathrm{cm} / \mathrm{sec}^{3}\right) \\
\text { PGV }(\mathrm{cm} / \mathrm{s})\end{array}$ & 219 & M5P \\
\hline
\end{tabular}

\section{CONCLUSIONS}

Six models of R.C frame buildings dynamically analyzed under application of several ground motion time histories. Machine learning method used to correlate between various types of ground motion IMs and the structural response of buildings in terms of top displacement. With regard to possibility of using jerk and its based paramaters as IM, it has been shown that the jerk-based parameters are only effective when they are used to predict the seismic response of structures with low nonlinearity. Furthermore, it was shown that no single learning algorithm used by machine learning process has been found to be superior to all of the others for the problem discussed in this study. Hence, the bias produced by using different learning algorithms and classifiers should not be ignored.

\section{REFERENCES}

American Society of Civil Engineers (ASCE). (2017). Seismic evaluation and retrofit of existing buildings, Standard ASCE/SEI 41-17. Reston, VA.: American Society of Civil Engineers/Structural Engineering Institute.

American Society of Civil Engineers (ASCE). (2007). Seismic rehabilitation of existing buildings, ASCE/SEI 41-06. Reston, VA.: American Society of Civil Engineers/Structural Engineering Institute.

An YH, Jo HK, Spencer FB, \&Ou JP. (2014) A damage localization method based on the 'jerk energy'. Smart Materials and Structures, 23(2).

a.yaseen@uod.ac, mezgeen@uod.ac, yaman.alkamaki@uod.ac ${ }^{1}$ Corresponding author: College of Engineering, University of Duhok, Kurdistan Region, Iraq 
Applied Technology Council (ATC). (2011). ATC-58, Guidelines for Seismic Performance Assessment of Buildings, $75 \%$ Draft. Redwood City, CA

Arias, A. (1970). A Measure of Earthquake Intensity. In R. Hansen(Ed.), Seismic Design for Nuclear Power Plants (pp. 438-483). Cambridge Massachusetts: MIT Press.

Buratti, N. (2012). A comparison of the performances of various ground-motion intensity measures. Paper presented at the Proceedings of the 15th world conference on earthquake engineering, Lisbon, Portugal.

Caruana, R., \&Freitag, D. (1994). Greedy attribute selection. In Machine Learning: Proceedings of the Eleventh International Conference. Morgan Kaufmann.

CEN (2003). Eurocode 8 - Design of Structures for Earthquake Resistance, Part 1: General rules, seismic action, and rules for buildings (Report). Brussels: European Union, European Committee for Standardization.

Computers and Structures, Inc. (2016), ETABS.

Elenas, A. (2013). Intensity Parameters as Damage Potential Descriptors of Earthquakes. In M. Papadrakakis, G. Stefanou, \& V. Papadopoulos(Eds.), Computational Methods in Stochastic Dynamics (pp. 327-334). Springer Netherlands.

He, H., Li, R., \& Chen, K. (2015). Characteristics of Jerk Response Spectra for Elastic and Inelastic Systems. Shock and Vibration, pp. 1-12.

He, H.X., Yan, W.M.,Chen, Y.J.(2011). Study on concept and characteristics of seismic jerk response spectra. Engineering Mechanics, 28(11).

Holmes, G., Donkin, A., \& Witten, I.H. (1994). Weka: A machine learning workbench. In Proceedings of the Second Australia and New Zealand Conference on Intelligent Information Systems.

Housner, G. W. (1952). Spectrum Intensities of Strong-Motion Earthquakes. Paper presented at the Proceedings of the Symposium on Earthquake and Blast Effectrs on Structures, pp. 20-36.

Housner, G. W., \& Jennings, P. C. (1964). Generation of artificial earthquakes. Journal of the Engineering Mechanics Division, EM1, pp. 113-150.

Hrovat, D., \& Hubbard, M. (1987). A comparison between jerk optimal and acceleration optimal vibration isolation. Journal of Sound and Vibration, 112(2), pp. 201-210.

John, G. H., \& Langley, P. (1996). Static versus dynamic sampling for data mining. In Proceedings of the Second International Conference on Knowledge Discovery and Data Mining. AAAI Press.

John, G. H., Kohavi, R., \&Pfleger, P. (1994).
Irrelevant features and the subset selection problem. In Machine Learning: Proceedings of the Eleventh International Conference. Morgan Kaufmann.

Kohavi, R. (1995). Wrappers for performance enhancement and oblivious decision graphs. $\mathrm{PhD}$ thesis, Stanford University.

Kohavi, R., \& John, G. (1996). Wrappers for feature subset selection. Artificial Intelligence, special issue on relevance, 97(1-2), pp.273-324.

Kramer, S. L. (1996). Geotechnical Earthquake Engineering. New Jersey: Prentice-Hall.

Langley, P., \& Simon, H. A. (1995). Applications of machine learning and rule induction. Communications of the ACM, 38(11), pp. 5564.

Liu, C., Gazis, D. C., \& Kennedy, T. W. (1999). Human judgment and analytical derivation of ride quality. Transportation Science, 33(3), pp. 290-297.

Nanos, N. (2011). A study on the importance of seismic parameter selection for the vulnerability assessment of mid-rise reinforced concrete structures. PhD Thesis, University of Portsmouth, UK.

Qiao, YF. (1990). GIBBS-APPELL'S equations of variable mass nonlinear non holonomic mechanical systems. Applied Mathematics and Mechanics,11(10), pp.973-983.

Riddell, R. (2006). Correlation between Ground Motion Intensity Indices and Structural Response to Earthquakes. In J.J. Perez Gavilan (ed.), Earthquake Engineering Challenges and Trends (pp. 521-536). Mexico: Instituto de Ingeniera UNAM.

Schot, S. H. (1978). Jerk: the time rate of change of acceleration. The American Journal of Physics, 11(46), p. 1090.

SeismoSoft, (2018).SeismoSignal: A computer program for signal processing of strongmotion data. S Antoniou, R Pinho. Technical Report 4.0. 0. Pavia, Italy.

Shome, N., Cornell, C. A., Bazzurro, P., \& Carballo, J. E. (1998). Earthquakes, records, and nonlinear responses. Earthquake Spectra, 14(3), pp. 469-500.

Sofronie, R. (2017). On the Seismic Jerk. Journal of Geological Resource and Engineering, 5(4).

Tong, M., Wang, G.-Q., \& Lee, G. C. (2005). Time derivative of earthquake acceleration. Earthquake Engineering and Engineering Vibration, 4(1), 1-16.

Toshiyuki, A., Yutaka, S., \&Tomokazu, I. (2009). Cycle slip detection in kinematic GPS with a jerk model for land vehicles, International Journal of Innovative Computing Information and Control, 21(4), pp. 153-166.

Yaseen, A. A., (2015). Seismic fragility assessment of masonry buildings in the Kurdistan region. $\mathrm{PhD}$ thesis, University of Portsmouth, UK.

a.yaseen@uod.ac, mezgeen@uod.ac, yaman.alkamaki@uod.ac 
Journal of University of Duhok, Vol. 23, No.2 (Pure and Eng. Sciences), Pp 254-277, 2020 (Special Issue)

$3^{\text {rd }}$ international conference on recent innovations in engineering (ICRIE) Duhok, September 9-10-2020

\section{Appendix}

Table (A1): Jerk-based IMs defined for all the ground motion records considered in this study

\begin{tabular}{|c|c|c|c|c|c|c|c|c|c|c|c|}
\hline $\begin{array}{c}\text { NGA } \\
\text { Record } \\
\text { Number }\end{array}$ & $\begin{array}{c}P G J \\
\left(\mathrm{~cm} / \mathbf{s}^{3}\right)\end{array}$ & $\begin{array}{c}\text { Time of } \\
\text { Max. } \\
\text { Jerk (s) }\end{array}$ & $\begin{array}{l}\text { JRMS } \\
\left(\mathrm{cm} / \mathrm{s}^{3}\right)\end{array}$ & $\begin{array}{l}\text { IAJ } \\
\left(\mathrm{m} / \mathrm{s}^{2}\right)\end{array}$ & ICJ & $\begin{array}{c}\text { JSI } \\
\left(\mathrm{cm} / \mathbf{s}^{2}\right)\end{array}$ & $\begin{array}{c}\mathrm{SMJ} \\
\left(\mathrm{cm} / \mathbf{s}^{3}\right)\end{array}$ & $\begin{array}{c}\text { J95 } \\
\text { parameter } \\
\left(\mathrm{cm} / \mathrm{s}^{3}\right)\end{array}$ & $\begin{array}{l}\text { Sj,avg } \\
\left(\mathrm{cm} / \mathrm{s}^{3}\right)\end{array}$ & $\begin{array}{c}\mathrm{Tb}(2000) \\
\text { (s) }\end{array}$ & $\begin{array}{c}\mathrm{JE} \\
\left(\mathrm{cm} / \mathrm{s}^{3}\right)^{2}\end{array}$ \\
\hline 126 & 44593.7 & 6.8 & 7953.7 & 16470.6 & 2860318.8 & 11820.5 & 43631.3 & 44258.0 & 4060.2 & 12.7 & 11.3 \\
\hline 143 & 22223.9 & 10.0 & 3831.2 & 7713.7 & 1358548.7 & 18827.5 & 20383.6 & 21718.1 & 5357.1 & 25.1 & 10.4 \\
\hline 568 & 15690.9 & 1.7 & 2737.2 & 1082.1 & 430100.5 & 12129.4 & 10985.7 & 15651.6 & 3889.2 & 4.7 & 10.1 \\
\hline 825 & 47527.1 & 2.9 & 3081.0 & 4556.9 & 936390.4 & 21924.2 & 14124.3 & 47408.1 & 4738.8 & 19.3 & 10.2 \\
\hline 828 & 13564.0 & 4.0 & 1628.2 & 1527.2 & 394069.1 & 7086.3 & 10447.6 & 13461.9 & 2974.1 & 24.8 & 9.7 \\
\hline 963 & 15215.0 & 8.2 & 1228.9 & 966.9 & 272408.4 & 9967.5 & 8300.8 & 15100.4 & 3350.8 & 19.4 & 9.5 \\
\hline 983 & 14689.5 & 6.8 & 1806.4 & 1494.9 & 410667.0 & 9891.2 & 11009.8 & 14504.8 & 3737.5 & 10.7 & 10.3 \\
\hline 1004 & 26586.9 & 7.7 & 1900.4 & 2762.0 & 572541.7 & 10280.3 & 16224.5 & 26386.7 & 4999.2 & 15.0 & 10.5 \\
\hline 1085 & 21351.0 & 3.5 & 1735.4 & 1928.7 & 457203.8 & 12074.2 & 12632.3 & 21190.2 & 4834.1 & 19.9 & 10.4 \\
\hline 1086 & 10960.7 & 3.9 & 1020.7 & 666.9 & 206183.6 & 7661.9 & 5993.4 & 10878.2 & 3721.6 & 10.0 & 9.3 \\
\hline 1197 & 38478.9 & 37.9 & 1675.5 & 4045.4 & 650623.9 & 12027.0 & 23654.2 & 38382.6 & 5033.5 & 39.2 & 10.7 \\
\hline 1507 & 21486.4 & 35.3 & 2194.1 & 6937.4 & 974998.6 & 13648.8 & 18934.3 & 21216.1 & 3981.9 & 58.9 & 10.9 \\
\hline 1508 & 15966.4 & 35.8 & 1503.7 & 3258.5 & 553185.6 & 8453.4 & 14612.7 & 15684.5 & 3711.3 & 44.0 & 10.6 \\
\hline 169 & 8378.0 & 8.8 & 1023.2 & 1674.7 & 327129.3 & 5386.0 & 7842.5 & 8101.1 & 1845.5 & 28.6 & 10.0 \\
\hline 179 & 10422.0 & 5.2 & 970.5 & 588.0 & 188784.2 & 4127.1 & 9150.0 & 10343.5 & 2136.5 & 10.1 & 9.9 \\
\hline 182 & 8333.0 & 4.8 & 748.8 & 330.6 & 124335.7 & 4135.1 & 5295.0 & 8270.3 & 3295.2 & 8.3 & 9.6 \\
\hline 184 & 15128.0 & 5.6 & 1668.6 & 1736.7 & 425422.8 & 9632.9 & 11379.0 & 14937.7 & 2465.6 & 11.2 & 10.3 \\
\hline 802 & 13902.7 & 7.4 & 1440.0 & 1326.4 & 345375.8 & 7714.3 & 12564.5 & 13727.8 & 3023.6 & 10.8 & 10.2 \\
\hline 821 & 15865.0 & 3.5 & 1394.9 & 647.2 & 237447.7 & 7927.3 & 8438.0 & 15825.3 & 3455.2 & 11.3 & 9.9 \\
\hline 953 & 12534.1 & 7.4 & 1324.8 & 842.5 & 264018.7 & 7347.5 & 10342.3 & 12439.7 & 3866.8 & 9.9 & 9.7 \\
\hline 959 & 18253.5 & 6.5 & 1758.9 & 1237.5 & 368697.8 & 7662.9 & 10343.0 & 18116.1 & 2447.2 & 12.9 & 9.9 \\
\hline 1013 & 17719.0 & 4.7 & 1584.3 & 1067.9 & 325050.6 & 6817.9 & 12103.0 & 17585.6 & 3668.2 & 9.7 & 10.1 \\
\hline 1044 & 17816.5 & 5.4 & 1567.2 & 1572.3 & 392280.0 & 12613.4 & 10713.3 & 17682.4 & 3825.1 & 8.3 & 9.7 \\
\hline
\end{tabular}

a.yaseen@uod.ac, ezgeen@uod.ac, yaman.alkamaki@uod.ac

${ }^{1}$ Corresponding author: College of Engineering, University of Duhok, Kurdistan Region, Iraq 
Journal of University of Duhok, Vol. 23, No.2 (Pure and Eng. Sciences), Pp 254-277, 2020 (Special Issue)

$3^{\text {rd }}$ international conference on recent innovations in engineering (ICRIE) Duhok, September 9-10-2020

\begin{tabular}{cccccccccccc}
\hline 1063 & 19332.7 & 2.4 & 2985.9 & 2840.9 & 727848.0 & 11591.5 & 15808.1 & 19089.5 & 7251.0 & 16.9 & 10.2 \\
\hline 1119 & 10882.5 & 6.0 & 1133.0 & 841.7 & 244049.9 & 10363.5 & 10545.0 & 10800.6 & 4675.7 & 4.9 & 9.7 \\
\hline 1602 & 21590.0 & 10.7 & 1284.3 & 1476.1 & 344089.8 & 12348.8 & 10829.0 & 21536.0 & 3850.3 & 12.2 & 10.0 \\
\hline 1605 & 9406.0 & 3.6 & 1320.1 & 722.1 & 243989.9 & 7645.6 & 8986.0 & 9287.7 & 2659.8 & 10.3 & 10.0 \\
\hline
\end{tabular}

Table (A2): Commonly used ground-motion IMs defined for all the ground motion records considered in this study

\begin{tabular}{|c|c|c|c|c|c|c|c|c|c|c|c|c|c|c|c|c|c|c|c|c|c|c|}
\hline $\begin{array}{c}\text { NGA } \\
\text { Record } \\
\text { Number }\end{array}$ & $\begin{array}{l}\text { PGA } \\
\left(\mathrm{m} / \mathrm{s}^{2}\right)\end{array}$ & $\begin{array}{c}\text { PGV } \\
\text { (cm/s) }\end{array}$ & $\begin{array}{l}\text { PGD } \\
\text { (cm) }\end{array}$ & $\begin{array}{l}\text { ARMS } \\
\left(\mathrm{m} / \mathrm{s}^{2}\right)\end{array}$ & $\begin{array}{l}\text { VRMS } \\
(\mathrm{cm} / \mathrm{s})\end{array}$ & $\begin{array}{c}\text { DRMS } \\
\text { (cm) }\end{array}$ & $\begin{array}{c}\mathrm{IA} \\
(\mathrm{m} / \mathrm{s})\end{array}$ & Ic & $\begin{array}{c}\text { SED } \\
\left(\mathrm{cm}^{2} / \mathrm{s}\right)\end{array}$ & $\begin{array}{c}\text { CAV } \\
(\mathrm{cm} / \mathrm{s})\end{array}$ & $\begin{array}{l}\text { ASI } \\
(\mathrm{m} / \mathrm{s})\end{array}$ & $\begin{array}{l}\text { VSI } \\
\text { (cm) }\end{array}$ & $\begin{array}{c}\text { IH } \\
\text { (cm) }\end{array}$ & $\begin{array}{l}\text { SMA } \\
\left(\mathrm{m} / \mathrm{s}^{2}\right)\end{array}$ & $\begin{array}{c}\mathrm{SMV} \\
(\mathrm{cm} / \mathrm{s})\end{array}$ & $\begin{array}{l}\text { EDA } \\
\left(\mathrm{m} / \mathrm{s}^{2}\right)\end{array}$ & $\begin{array}{c}\text { A95 } \\
\left(\mathrm{m} / \mathrm{s}^{2}\right)\end{array}$ & $\begin{array}{l}\mathrm{TP} \\
(\mathrm{s})\end{array}$ & $\begin{array}{l}\mathrm{Tm} \\
(\mathbf{s})\end{array}$ & $\begin{array}{l}\text { Sa,ave. } \\
\left(\mathrm{cm} / \mathbf{s}^{2}\right)\end{array}$ & $\begin{array}{c}\text { IP } \\
\text { Index }\end{array}$ & $\begin{array}{c}\text { Damage } \\
\text { index }\end{array}$ \\
\hline 126 & 6.0 & 65.4 & 25.4 & 1.3 & 17.8 & 9.8 & 4.7 & 6.2 & 5172.6 & 1360.6 & 4.7 & 230.2 & 213.5 & 5.6 & 47.1 & 5.3 & 5.9 & 0.1 & 0.4 & 5.2 & 20.5 & 1581.4 \\
\hline 143 & 8.2 & 97.8 & 38.7 & 1.5 & 20.8 & 13.5 & 11.5 & 10.3 & 14190.0 & 3052.9 & 8.0 & 339.3 & 324.3 & 6.7 & 62.3 & 8.5 & 8.0 & 0.2 & 0.5 & 7.9 & 30.0 & 2034.4 \\
\hline 568 & 8.6 & 59.3 & 12.4 & 1.3 & 15.8 & 3.9 & 2.5 & 4.5 & 2248.3 & 719.8 & 6.0 & 240.8 & 227.6 & 4.4 & 48.7 & 8.2 & 8.6 & 0.2 & 0.6 & 5.7 & 12.1 & 301.3 \\
\hline 825 & 1.47 & 125.1 & 39.7 & 1.1 & 13.2 & 10.6 & 6.0 & 6.4 & 5188.0 & 1416.3 & 9.3 & 275.6 & 231.6 & 4.1 & 21.2 & 16.2 & 14.7 & 0.3 & 0.4 & 6.1 & 10.7 & 1011.9 \\
\hline 828 & 5.8 & 48.1 & 21.9 & 0.8 & 8.3 & 4.5 & 3.4 & 4.1 & 2500.9 & 1518.7 & 3.6 & 197.9 & 161.1 & 4.2 & 28.1 & 5.4 & 5.7 & 0.7 & 0.5 & 3.7 & 30.3 & 479.8 \\
\hline 963 & 5.6 & 51.8 & 9.0 & 0.7 & 7.3 & 2.4 & 2.8 & 3.4 & 2110.5 & 1305.3 & 5.1 & 212.4 & 183.9 & 4.0 & 32.5 & 5.9 & 5.5 & 0.3 & 0.5 & 4.6 & 24.8 & 357.7 \\
\hline 983 & 5.6 & 76.0 & 42.4 & 0.8 & 16.3 & 8.7 & 3.2 & 4.1 & 7625.1 & 1283.9 & 4.9 & 244.0 & 244.4 & 4.1 & 64.8 & 5.5 & 5.6 & 0.4 & 0.8 & 5.7 & 16.9 & 399.9 \\
\hline 1004 & 7.3 & 78.1 & 13.4 & 0.8 & 9.3 & 2.9 & 4.7 & 4.8 & 4162.2 & 1686.2 & 5.1 & 318.1 & 262.5 & 5.0 & 43.0 & 7.3 & 7.3 & 0.7 & 0.6 & 6.0 & 21.6 & 585.3 \\
\hline 1085 & 8.1 & 117.5 & 34.5 & 0.8 & 14.4 & 6.9 & 4.5 & 4.9 & 8250.4 & 1465.5 & 5.7 & 306.8 & 301.4 & 4.0 & 52.2 & 8.4 & 8.1 & 0.4 & 0.7 & 7.2 & 12.5 & 463.9 \\
\hline 1086 & 5.9 & 78.1 & 16.8 & 0.6 & 10.6 & 4.0 & 2.6 & 3.2 & 4496.2 & 1164.9 & 4.1 & 259.4 & 261.2 & 3.4 & 49.2 & 5.6 & 5.9 & 0.5 & 0.8 & 6.0 & 14.7 & 220.4 \\
\hline 1197 & 6.4 & 72.8 & 14.7 & 0.6 & 7.8 & 2.9 & 5.3 & 4.5 & 5455.4 & 2070.0 & 6.1 & 312.5 & 289.6 & 5.6 & 56.9 & 5.8 & 6.3 & 0.3 & 0.6 & 6.9 & 28.8 & 618.0 \\
\hline 1507 & 5.6 & 44.4 & 13.8 & 0.8 & 8.3 & 2.9 & 9.3 & 6.8 & 6133.2 & 3556.9 & 5.7 & 238.3 & 213.2 & 5.1 & 38.7 & 5.6 & 5.3 & 0.3 & 0.4 & 5.3 & 80.4 & 1574.0 \\
\hline 1508 & 4.8 & 71.7 & 38.7 & 0.6 & 8.8 & 10.2 & 5.8 & 4.8 & 7047.0 & 2618.5 & 4.3 & 246.1 & 225.0 & 3.8 & 46.0 & 4.7 & 4.7 & 0.7 & 0.6 & 5.1 & 36.8 & 607.1 \\
\hline 169 & 2.3 & 26.0 & 11.9 & 0.4 & 6.6 & 4.4 & 2.4 & 2.4 & 4298.2 & 2524.7 & 2.4 & 115.6 & 109.3 & 2.1 & 20.7 & 2.2 & 2.2 & 0.5 & 0.6 & 2.6 & 96.5 & 333.5 \\
\hline 179 & 3.5 & 76.6 & 59.1 & 0.4 & 15.7 & 12.5 & 0.9 & 1.5 & 9570.9 & 758.3 & 2.4 & 148.6 & 179.9 & 2.4 & 43.4 & 3.3 & 3.5 & 0.2 & 1.3 & 4.0 & 9.9 & 86.5 \\
\hline 182 & 4.5 & 109.3 & 44.8 & 0.5 & 16.7 & 10.7 & 1.7 & 2.4 & 10219.8 & 795.6 & 3.1 & 242.7 & 265.0 & 2.2 & 57.4 & 4.4 & 4.5 & 0.7 & 1.3 & 5.8 & 7.3 & 79.0 \\
\hline 184 & 3.5 & 71.3 & 45.9 & 0.5 & 11.5 & 9.8 & 1.7 & 2.4 & 5147.1 & 986.9 & 3.4 & 151.9 & 146.6 & 3.2 & 44.7 & 3.4 & 3.4 & 0.2 & 0.5 & 3.5 & 13.9 & 353.7 \\
\hline 802 & 5.0 & 41.2 & 16.2 & 0.5 & 7.2 & 3.2 & 1.5 & 2.1 & 2044.6 & 911.2 & 3.0 & 191.3 & 175.7 & 3.0 & 28.5 & 4.7 & 5.0 & 0.2 & 0.6 & 4.2 & 22.2 & 239.9 \\
\hline 821 & 4.9 & 64.3 & 21.9 & 0.7 & 14.5 & 7.3 & 1.8 & 2.9 & 4394.8 & 868.0 & 3.9 & 224.7 & 217.1 & 3.2 & 46.1 & 4.8 & 4.8 & 0.3 & 0.8 & 5.1 & 13.5 & 145.8 \\
\hline 953 & 4.1 & 59.0 & 13.2 & 0.8 & 10.9 & 2.6 & 3.1 & 3.9 & 3572.4 & 1428.3 & 3.5 & 266.3 & 237.6 & 3.5 & 38.7 & 3.9 & 4.0 & 0.5 & 0.7 & 5.2 & 24.2 & 254.9 \\
\hline 959 & 3.5 & 32.1 & 9.1 & 0.7 & 8.1 & 2.8 & 2.0 & 2.9 & 1625.5 & 1150.0 & 3.4 & 149.6 & 140.1 & 3.0 & 28.3 & 3.6 & 3.4 & 0.3 & 0.5 & 3.4 & 35.6 & 288.7 \\
\hline
\end{tabular}

a.yaseen@uod.ac, mezgeen@uod.ac, yaman.alkamaki@uod.ac

${ }^{1}$ Corresponding author: College of Engineering, University of Duhok, Kurdistan Region, Iraq 
Journal of University of Duhok, Vol. 23, No.2 (Pure and Eng. Sciences), Pp 254-277, 2020 (Special Issue)

$3^{\text {rd }}$ international conference on recent innovations in engineering (ICRIE) Duhok, September 9-10-2020

\begin{tabular}{|c|c|c|c|c|c|c|c|c|c|c|c|c|c|c|c|c|c|c|c|c|c|c|}
\hline 1013 & 5.0 & 63.7 & 21.3 & 0.6 & 12.0 & 5.3 & 1.8 & 2.7 & 3795.3 & 858.6 & 3.2 & 245.2 & 246.0 & 3.0 & 42.2 & 4.8 & 5.0 & 0.3 & 0.9 & 5.6 & 13.4 & 151.0 \\
\hline 1044 & 5.7 & 75.0 & 17.8 & 0.8 & 9.5 & 3.5 & 4.4 & 4.7 & 3589.4 & 1456.8 & 6.3 & 240.7 & 236.6 & 5.1 & 42.2 & 6.3 & 5.6 & 0.3 & 0.5 & 5.7 & 19.1 & 526.3 \\
\hline 1063 & 6.3 & 160.2 & 29.6 & 1.5 & 23.2 & 7.7 & 7.5 & 8.5 & 10713.2 & 1800.4 & 6.4 & 505.9 & 453.8 & 5.2 & 50.2 & 8.0 & 8.0 & 0.7 & 0.8 & 10.1 & 11.1 & 711.6 \\
\hline 1119 & 6.8 & 68.4 & 26.7 & 0.7 & 11.1 & 4.1 & 3.1 & 3.6 & 5028.0 & 1092.0 & 5.0 & 317.6 & 315.5 & 4.4 & 51.9 & 6.5 & 6.8 & 0.5 & 0.8 & 7.3 & 16.0 & 315.8 \\
\hline 1602 & 7.1 & 56.5 & 23.1 & 0.6 & 8.4 & 5.6 & 3.7 & 3.9 & 3901.3 & 1479.6 & 6.3 & 235.0 & 211.4 & 4.3 & 40.6 & 6.0 & 7.1 & 0.3 & 0.5 & 5.3 & 26.3 & 446.3 \\
\hline 1605 & 3.4 & 60.0 & 42.1 & 0.8 & 19.6 & 16.2 & 2.7 & 3.7 & 9945.3 & 1361.2 & 4.3 & 173.5 & 179.2 & 3.0 & 55.5 & 3.3 & 3.4 & 0.4 & 0.7 & 4.1 & 22.7 & 255.0 \\
\hline
\end{tabular}

Table (A3): Top displacement response (in x direction) of regular and irregular set back ${ }^{1}$ shape RC frame buildings

\begin{tabular}{|c|c|c|c|c|c|c|c|c|c|c|}
\hline $\begin{array}{c}\text { NGA } \\
\text { Record } \\
\text { Number }\end{array}$ & $\begin{array}{c}\text { Top } \\
\text { Displacement } \\
\text { Three story } \\
(\mathrm{mm}) \text { Regular }\end{array}$ & $\begin{array}{c}\text { Top } \\
\text { Displacement } \\
\text { Five story } \\
(\mathrm{mm}) \text { Regular }\end{array}$ & $\begin{array}{c}\text { Top } \\
\text { Displacement } \\
\text { Seven story } \\
(\mathrm{mm}) \text { Regular }\end{array}$ & $\begin{array}{c}\text { Top } \\
\text { Displacement } \\
\text { Ten story } \\
(\mathrm{mm}) \text { Regular }\end{array}$ & $\begin{array}{c}\text { Top } \\
\text { Displacement } \\
\text { Thirteen } \\
\text { story }(\mathbf{m m}) \\
\text { Regular }\end{array}$ & $\begin{array}{c}\text { Top } \\
\text { Displacement } \\
\text { Fifteen story } \\
(\mathrm{mm}) \text { Regular }\end{array}$ & $\begin{array}{c}\text { Top } \\
\text { Displacement } \\
\text { Three story } \\
(\mathrm{mm}) \text { Set } \\
\text { Back }^{1} \text { shape }\end{array}$ & $\begin{array}{c}\text { Top } \\
\text { Displacement } \\
\text { Five story } \\
(\mathrm{mm}) \text { Set } \\
\text { Back }^{1} \text { shape }\end{array}$ & $\begin{array}{c}\text { Top } \\
\text { Displacement } \\
\text { Ten story } \\
(\mathrm{mm}) \text { Set } \\
\text { Back }^{1} \text { shape }\end{array}$ & $\begin{array}{c}\text { Top } \\
\text { Displacement } \\
\text { Fifteen story } \\
(\mathbf{m m}) \\
\text { Set Back }{ }^{1} \\
\text { shape } \\
\end{array}$ \\
\hline 126 & 69.5 & 172.4 & 237.2 & 334.4 & 351.4 & 274.7 & 65.4 & 203.8 & 348.1 & 268.7 \\
\hline 143 & 94.8 & 275.7 & 259.9 & 391.1 & 526.9 & 761.9 & 129.4 & 245.9 & 428.2 & 756.8 \\
\hline 568 & 106.8 & 206.7 & 246.4 & 292.2 & 333.7 & 392.0 & 92.6 & 219.4 & 302.2 & 381.3 \\
\hline 825 & 128.5 & 197.7 & 226.8 & 311.5 & 325.3 & 349.3 & 128.5 & 217.6 & 320.2 & 366.7 \\
\hline 828 & 84.2 & 239.8 & 205.8 & 169.1 & 216.7 & 211.0 & 66.9 & 261.0 & 173.2 & 219.0 \\
\hline 963 & 80.2 & 161.6 & 164.4 & 260.9 & 335.6 & 318.3 & 86.1 & 140.3 & 281.5 & 307.3 \\
\hline 983 & 55.7 & 178.0 & 187.6 & 261.9 & 459.8 & 639.5 & 62.6 & 149.8 & 272.2 & 661.3 \\
\hline 1004 & 119.4 & 284.9 & 359.1 & 360.8 & 405.1 & 397.4 & 109.4 & 317.1 & 370.2 & 383.4 \\
\hline 1085 & 99.5 & 213.3 & 237.7 & 353.0 & 459.2 & 661.4 & 106.6 & 228.5 & 364.2 & 703.3 \\
\hline 1086 & 110.4 & 124.5 & 216.9 & 321.5 & 474.5 & 676.7 & 102.0 & 147.4 & 340.8 & 698.9 \\
\hline 1197 & 143.3 & 192.9 & 340.4 & 250.1 & 541.3 & 634.8 & 103.3 & 256.1 & 257.3 & 637.9 \\
\hline 1507 & 96.8 & 153.0 & 214.6 & 314.6 & 278.6 & 348.4 & 71.3 & 158.4 & 337.0 & 400.0 \\
\hline 1508 & 84.6 & 252.0 & 326.1 & 276.5 & 361.4 & 282.0 & 104.3 & 268.3 & 299.8 & 285.7 \\
\hline 169 & 50.8 & 93.9 & 102.5 & 119.7 & 197.2 & 238.0 & 57.5 & 95.7 & 128.5 & 240.0 \\
\hline 179 & 47.5 & 70.8 & 141.8 & 217.6 & 363.4 & 483.9 & 48.9 & 67.4 & 222.6 & 504.5 \\
\hline 182 & 66.7 & 232.4 & 216.8 & 323.6 & 510.8 & 691.6 & 78.8 & 234.7 & 345.2 & 691.3 \\
\hline
\end{tabular}

a.yaseen@uod.ac, mezgeen@uod.ac, yaman.alkamaki@uod.ac

${ }^{1}$ Corresponding author: College of Engineering, University of Duhok, Kurdistan Region, Iraq 
Journal of University of Duhok, Vol. 23, No.2 (Pure and Eng. Sciences), Pp 254-277, 2020 (Special Issue)

$3^{\text {rd }}$ international conference on recent innovations in engineering (ICRIE) Duhok, September 9-10-2020

\begin{tabular}{|c|c|c|c|c|c|c|c|c|c|c|}
\hline 184 & 49.0 & 123.6 & 76.5 & 137.6 & 279.9 & 445.4 & 50.5 & 126.0 & 146.7 & 460.2 \\
\hline 802 & 48.9 & 99.5 & 136.2 & 287.6 & 381.7 & 395.4 & 46.0 & 116.7 & 297.3 & 396.4 \\
\hline 821 & 70.4 & 158.7 & 179.1 & 261.0 & 386.3 & 484.1 & 63.5 & 189.5 & 264.8 & 507.2 \\
\hline 953 & 115.6 & 129.5 & 323.0 & 345.0 & 355.2 & 314.7 & 80.8 & 151.2 & 357.0 & 335.8 \\
\hline 959 & 66.3 & 100.0 & 114.7 & 184.1 & 303.3 & 327.1 & 82.6 & 122.4 & 190.5 & 307.4 \\
\hline 1013 & 58.8 & 146.7 & 221.6 & 339.4 & 452.8 & 624.5 & 57.1 & 148.4 & 350.2 & 609.7 \\
\hline 1044 & 109.5 & 123.7 & 219.2 & 396.0 & 303.1 & 387.7 & 75.8 & 162.1 & 430.5 & 390.8 \\
\hline 1063 & 142.2 & 352.5 & 559.1 & 728.4 & 785.0 & 775.0 & 140.3 & 368.6 & 742.7 & 745.4 \\
\hline 1119 & 108.0 & 234.1 & 285.2 & 464.8 & 647.8 & 603.2 & 141.3 & 262.9 & 493.1 & 578.6 \\
\hline 1602 & 130.0 & 155.4 & 215.5 & 218.8 & 322.8 & 369.3 & 125.7 & 148.3 & 223.4 & 384.3 \\
\hline 1605 & 86.2 & 178.3 & 172.4 & 179.6 & 260.9 & 306.6 & 107.3 & 175.2 & 194.6 & 334.4 \\
\hline
\end{tabular}

Table A4 Top displacement response (in $\mathrm{x}$ direction) of irregular set back ${ }^{2}$ and I shape RC frame buildings

\begin{tabular}{|c|c|c|c|c|c|c|c|c|}
\hline $\begin{array}{c}\text { NGA } \\
\text { Record } \\
\text { Number }\end{array}$ & $\begin{array}{c}\text { Top } \\
\text { Displacement } \\
\text { Three story } \\
(\mathrm{mm}) \text { Set Back } \\
\text { shape } \\
\end{array}$ & $\begin{array}{c}\text { Top } \\
\text { Displacement } \\
\text { Five story } \\
(\mathrm{mm}) \text { Set Back } \\
{ }^{2} \text { shape } \\
\end{array}$ & $\begin{array}{c}\text { Top } \\
\text { Displacement } \\
\text { Ten story } \\
\text { (mm) Set Back } \\
{ }^{2} \text { shape } \\
\end{array}$ & $\begin{array}{c}\text { Top } \\
\text { Displacement } \\
\text { Fifteen story } \\
(\mathrm{mm}) \text { Set Back } \\
\text { shape } \\
\end{array}$ & $\begin{array}{c}\text { Top } \\
\text { Displacement } \\
\text { Three story } \\
\text { (mm) } \\
\text { I shape } \\
\end{array}$ & $\begin{array}{c}\text { Top } \\
\text { Displacement } \\
\text { Five story } \\
\text { (mm) } \\
\text { I shape } \\
\end{array}$ & $\begin{array}{c}\text { Top } \\
\text { Displacement } \\
\text { Ten story } \\
\text { (mm) } \\
\text { I shape } \\
\end{array}$ & $\begin{array}{c}\text { Top } \\
\text { Displacement } \\
\text { Fifteen story } \\
(\mathrm{mm}) \quad \text { I shape }\end{array}$ \\
\hline 126 & 67.0 & 195.3 & 260.3 & 386.2 & 61.6 & 132.7 & 324.5 & 490.6 \\
\hline 143 & 102.0 & 183.1 & 490.4 & 776.6 & 93.4 & 159.8 & 488.4 & 693.5 \\
\hline 568 & 77.9 & 218.1 & 311.4 & 482.3 & 64.6 & 184.3 & 328.5 & 390.4 \\
\hline 825 & 106.2 & 208.2 & 309.6 & 367.6 & 92.8 & 195.0 & 346.8 & 372.8 \\
\hline 828 & 59.8 & 236.6 & 196.9 & 233.6 & 52.0 & 187.6 & 254.9 & 230.4 \\
\hline 963 & 83.5 & 116.1 & 215.1 & 371.5 & 86.0 & 130.0 & 195.0 & 478.8 \\
\hline 983 & 77.1 & 132.7 & 249.2 & 631.8 & 64.3 & 102.9 & 248.0 & 522.6 \\
\hline 1004 & 90.5 & 282.4 & 414.9 & 495.4 & 77.4 & 236.8 & 499.8 & 531.3 \\
\hline 1085 & 84.5 & 196.7 & 330.1 & 606.7 & 84.7 & 157.8 & 451.3 & 605.2 \\
\hline 1086 & 90.6 & 164.4 & 312.4 & 686.8 & 71.1 & 176.4 & 300.5 & 560.9 \\
\hline 1197 & 95.0 & 285.2 & 359.4 & 664.0 & 93.0 & 252.0 & 430.9 & 664.2 \\
\hline 1507 & 76.1 & 171.0 & 326.6 & 347.3 & 68.8 & 178.2 & 331.8 & 337.9 \\
\hline
\end{tabular}

a.yaseen@uod.ac, mezgeen@uod.ac, yaman.alkamaki@uod.ac

${ }^{1}$ Corresponding author: College of Engineering, University of Duhok, Kurdistan Region, Iraq 
Journal of University of Duhok, Vol. 23, No.2 (Pure and Eng. Sciences), Pp 254-277, 2020 (Special Issue)

$3^{\text {rd }}$ international conference on recent innovations in engineering (ICRIE) Duhok, September 9-10-2020

\begin{tabular}{|c|c|c|c|c|c|c|c|c|}
\hline 1508 & 88.9 & 225.4 & 283.0 & 367.2 & 77.2 & 137.2 & 349.5 & 394.9 \\
\hline 169 & 49.3 & 88.9 & 110.7 & 241.1 & 38.0 & 66.9 & 101.6 & 242.9 \\
\hline 179 & 41.9 & 55.3 & 272.2 & 452.4 & 31.8 & 54.2 & 284.9 & 454.8 \\
\hline 182 & 77.8 & 177.7 & 309.7 & 723.5 & 57.8 & 116.3 & 336.2 & 724.9 \\
\hline 184 & 39.0 & 100.1 & 154.7 & 406.2 & 33.7 & 63.4 & 161.9 & 358.1 \\
\hline 802 & 34.5 & 112.9 & 287.6 & 433.6 & 33.5 & 87.3 & 271.8 & 480.0 \\
\hline 821 & 54.4 & 173.6 & 275.3 & 550.8 & 47.1 & 129.7 & 301.0 & 547.3 \\
\hline 953 & 70.0 & 137.6 & 438.8 & 298.1 & 54.7 & 137.7 & 466.0 & 441.9 \\
\hline 959 & 61.8 & 135.7 & 138.4 & 419.6 & 43.9 & 130.2 & 113.3 & 355.8 \\
\hline 1013 & 47.8 & 133.9 & 477.1 & 651.9 & 45.2 & 111.8 & 383.4 & 567.7 \\
\hline 1044 & 74.5 & 165.2 & 458.3 & 405.3 & 77.4 & 184.0 & 420.9 & 403.1 \\
\hline 1063 & 131.7 & 333.2 & 851.9 & 933.1 & 117.2 & 260.1 & 823.9 & 1111.8 \\
\hline 1119 & 122.8 & 255.8 & 461.7 & 820.0 & 85.0 & 203.7 & 422.5 & 795.0 \\
\hline 1602 & 128.7 & 160.5 & 213.7 & 380.8 & 104.4 & 206.9 & 272.7 & 405.1 \\
\hline 1605 & 109.9 & 127.1 & 189.9 & 301.3 & 112.1 & 116.6 & 192.8 & 319.6 \\
\hline
\end{tabular}

Table (A5): Top displacement response (in x direction) of URM and irregular L and Plus shape RC frame buildings

\begin{tabular}{|c|c|c|c|c|c|c|c|c|c|c|}
\hline $\begin{array}{c}\text { NGA } \\
\text { Record } \\
\text { Number }\end{array}$ & $\begin{array}{c}\text { Top } \\
\text { Displacement } \\
\text { Three story }(\mathrm{mm}) \\
\text { L shape }\end{array}$ & $\begin{array}{c}\text { Top } \\
\text { Displacement } \\
\text { Five story }(\mathrm{mm}) \\
\text { L shape }\end{array}$ & $\begin{array}{c}\text { Top } \\
\text { Displacement } \\
\text { Ten story (mm) } \\
\text { L shape }\end{array}$ & $\begin{array}{c}\text { Top Displacement } \\
\text { Fifteen story }(\mathrm{mm}) \\
\text { L shape }\end{array}$ & $\begin{array}{c}\text { Top } \\
\text { Displacement } \\
\text { Three story } \\
\text { (mm) Plus shape }\end{array}$ & $\begin{array}{l}\text { Top Displacement } \\
\text { Five story (mm) } \\
\text { Plus shape }\end{array}$ & $\begin{array}{c}\text { Top Displacement } \\
\text { Ten story (mm) } \\
\text { Plus shape }\end{array}$ & $\begin{array}{c}\text { Top Displacement } \\
\text { Fifteen story (mm) } \\
\text { Plus shape }\end{array}$ & $\begin{array}{c}\text { Top } \\
\text { Displacement } \\
\text { One story } \\
\text { (mm) URM } \\
\text { Yaseen (2015) } \\
\end{array}$ & $\begin{array}{c}\text { Top } \\
\text { Displacement } \\
\text { Two story } \\
\text { (mm) URM } \\
\text { Yaseen (2015) }\end{array}$ \\
\hline 126 & 68.3 & 197.2 & 438.3 & 278.4 & 69.0 & 177.5 & 402.1 & 270.9 & 9.4 & 19.8 \\
\hline 143 & 101.0 & 309.0 & 428.5 & 842.7 & 98.2 & 288.4 & 395.6 & 754.0 & 18.1 & 45.6 \\
\hline 568 & 103.7 & 222.0 & 309.6 & 444.3 & 105.1 & 217.5 & 298.6 & 391.6 & 15.0 & 45.6 \\
\hline 825 & 130.1 & 204.4 & 322.7 & 414.5 & 129.3 & 202.2 & 315.6 & 375.4 & 23.4 & 42.6 \\
\hline 828 & 80.0 & 267.5 & 179.2 & 256.9 & 82.2 & 252.8 & 174.2 & 236.0 & 7.2 & 24.1 \\
\hline 963 & 79.7 & 201.6 & 314.3 & 318.4 & 80.7 & 189.6 & 288.0 & 304.7 & 8.5 & 21.5 \\
\hline 983 & 55.1 & 212.1 & 317.0 & 788.0 & 54.8 & 198.9 & 292.5 & 696.8 & 9.8 & 25.6 \\
\hline 1004 & 116.1 & 314.5 & 353.1 & 378.5 & 117.6 & 304.2 & 351.7 & 355.3 & 11.7 & 48.6 \\
\hline
\end{tabular}

a.yaseen@uod.ac, mezgeen@uod.ac, yaman.alkamaki@uod.ac

${ }^{1}$ Corresponding author: College of Engineering, University of Duhok, Kurdistan Region, Iraq 
Journal of University of Duhok, Vol. 23, No.2 (Pure and Eng. Sciences), Pp 254-277, 2020 (Special Issue)

$3^{\text {rd }}$ international conference on recent innovations in engineering (ICRIE) Duhok, September 9-10-2020

\begin{tabular}{|c|c|c|c|c|c|c|c|c|c|c|}
\hline 1085 & 101.9 & 289.8 & 467.4 & 806.9 & 101.3 & 269.1 & 425.8 & 731.3 & 13.9 & 32.4 \\
\hline 1086 & 109.9 & 182.6 & 342.0 & 806.1 & 110.7 & 178.6 & 319.5 & 715.5 & 8.7 & 24.4 \\
\hline 1197 & 139.3 & 204.0 & 259.2 & 667.9 & 141.8 & 186.1 & 233.0 & 618.8 & 12.2 & 32.2 \\
\hline 1507 & 92.2 & 184.3 & 431.5 & 523.1 & 95.3 & 171.8 & 372.5 & 456.9 & 9.1 & 22.8 \\
\hline 1508 & 86.2 & 278.5 & 357.6 & 288.9 & 86.7 & 263.4 & 321.9 & 263.9 & 10.7 & 24.8 \\
\hline 169 & 53.7 & 104.8 & 182.3 & 265.0 & 52.7 & 100.5 & 156.2 & 232.5 & 1.2 & 5.2 \\
\hline 179 & 48.3 & 82.1 & 252.6 & 569.8 & 48.0 & 79.5 & 241.7 & 530.9 & 1.1 & 6.4 \\
\hline 182 & 66.1 & 268.2 & 354.8 & 762.7 & 66.6 & 254.5 & 324.0 & 712.9 & 5.9 & 31.3 \\
\hline 184 & 49.9 & 139.2 & 163.6 & 535.0 & 49.4 & 130.3 & 152.6 & 486.8 & 3.5 & 9.0 \\
\hline 802 & 50.5 & 94.5 & 323.3 & 387.4 & 49.9 & 91.5 & 307.7 & 377.5 & 4.2 & 13.6 \\
\hline 821 & 70.2 & 168.6 & 264.2 & 594.6 & 70.8 & 159.2 & 259.9 & 516.0 & 6.4 & 27.0 \\
\hline 953 & 108.9 & 172.1 & 421.1 & 368.5 & 113.2 & 165.2 & 406.5 & 348.2 & 7.6 & 25.7 \\
\hline 959 & 71.9 & 106.7 & 185.8 & 391.9 & 69.8 & 101.9 & 168.6 & 309.6 & 3.2 & 7.9 \\
\hline 1013 & 59.0 & 164.4 & 353.2 & 689.6 & 59.6 & 160.1 & 333.1 & 590.9 & 6.8 & 26.0 \\
\hline 1044 & 103.2 & 133.7 & 406.8 & 431.3 & 107.0 & 131.1 & 362.7 & 388.3 & 11.8 & 27.8 \\
\hline 1063 & 141.1 & 400.9 & 751.1 & 721.1 & 141.6 & 387.5 & 733.8 & 717.5 & 14.4 & 70.2 \\
\hline 1119 & 118.1 & 249.5 & 555.7 & 572.7 & 114.1 & 241.3 & 497.3 & 557.0 & 11.7 & 27.5 \\
\hline 1602 & 130.6 & 180.5 & 241.9 & 421.7 & 130.0 & 173.0 & 234.0 & 387.5 & 11.7 & 27.4 \\
\hline 1605 & 88.5 & 202.3 & 252.2 & 396.1 & 88.0 & 191.6 & 222.5 & 357.2 & 5.0 & 16.4 \\
\hline
\end{tabular}

a.yaseen@uod.ac, mezgeen@uod.ac, yaman.alkamaki@uod.ac

${ }^{1}$ Corresponding author: College of Engineering, University of Duhok, Kurdistan Region, Iraq 
Table ( A6): Subsets of ground-motion IMs obtained from the first stage of feature selection process for the twenty seven earthquake record dataset (M5P learning algorithm was the algorithm with higher merit)

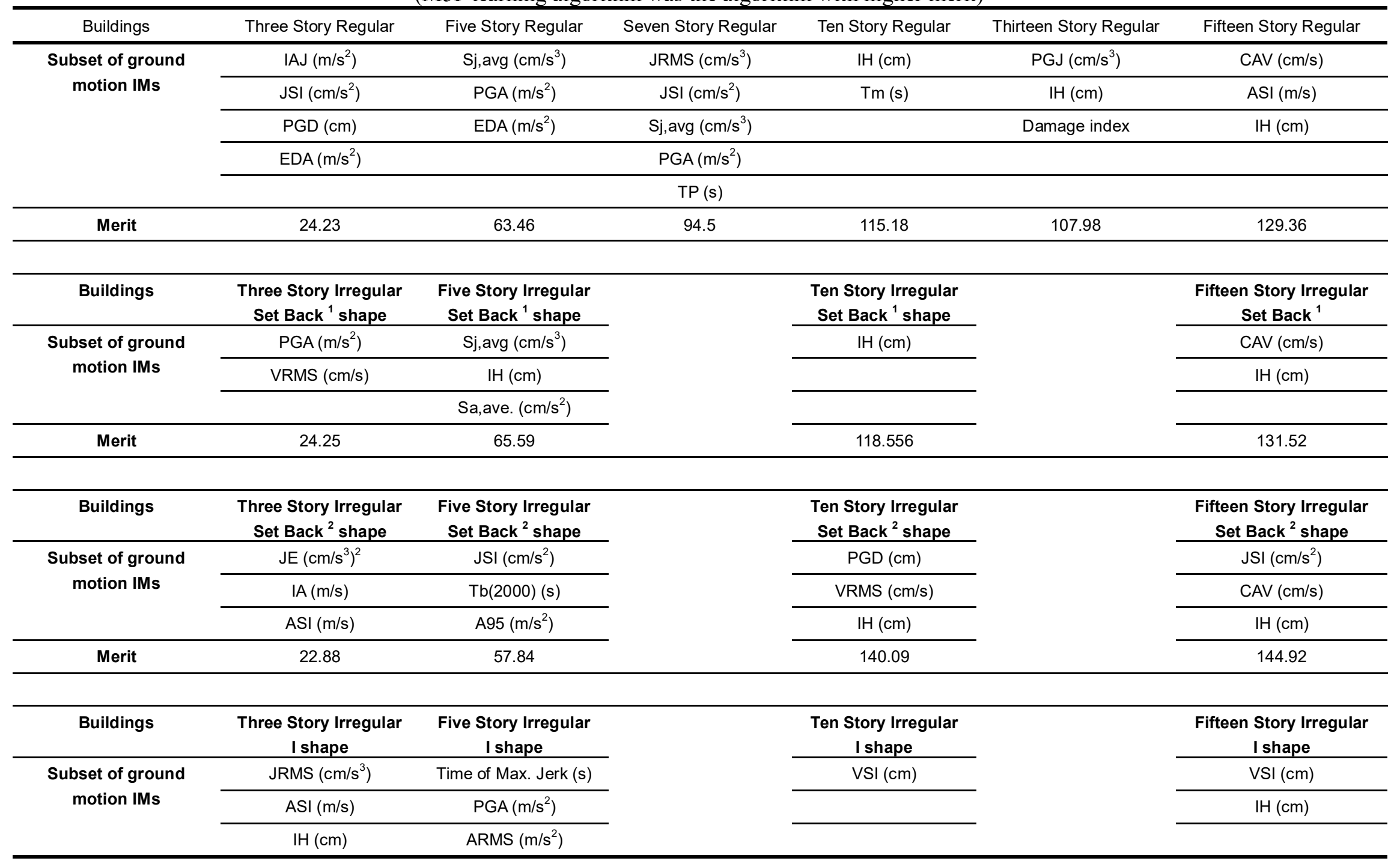

a.yaseen@uod.ac, mezgeen@uod.ac, yaman.alkamaki@uod.ac

${ }^{1}$ Corresponding author: College of Engineering, University of Duhok, Kurdistan Region, Iraq 
Journal of University of Duhok, Vol. 23, No.2 (Pure and Eng. Sciences), Pp 254-277, 2020 (Special Issue)

$3^{\text {rd }}$ international conference on recent innovations in engineering (ICRIE) Duhok, September 9-10-2020

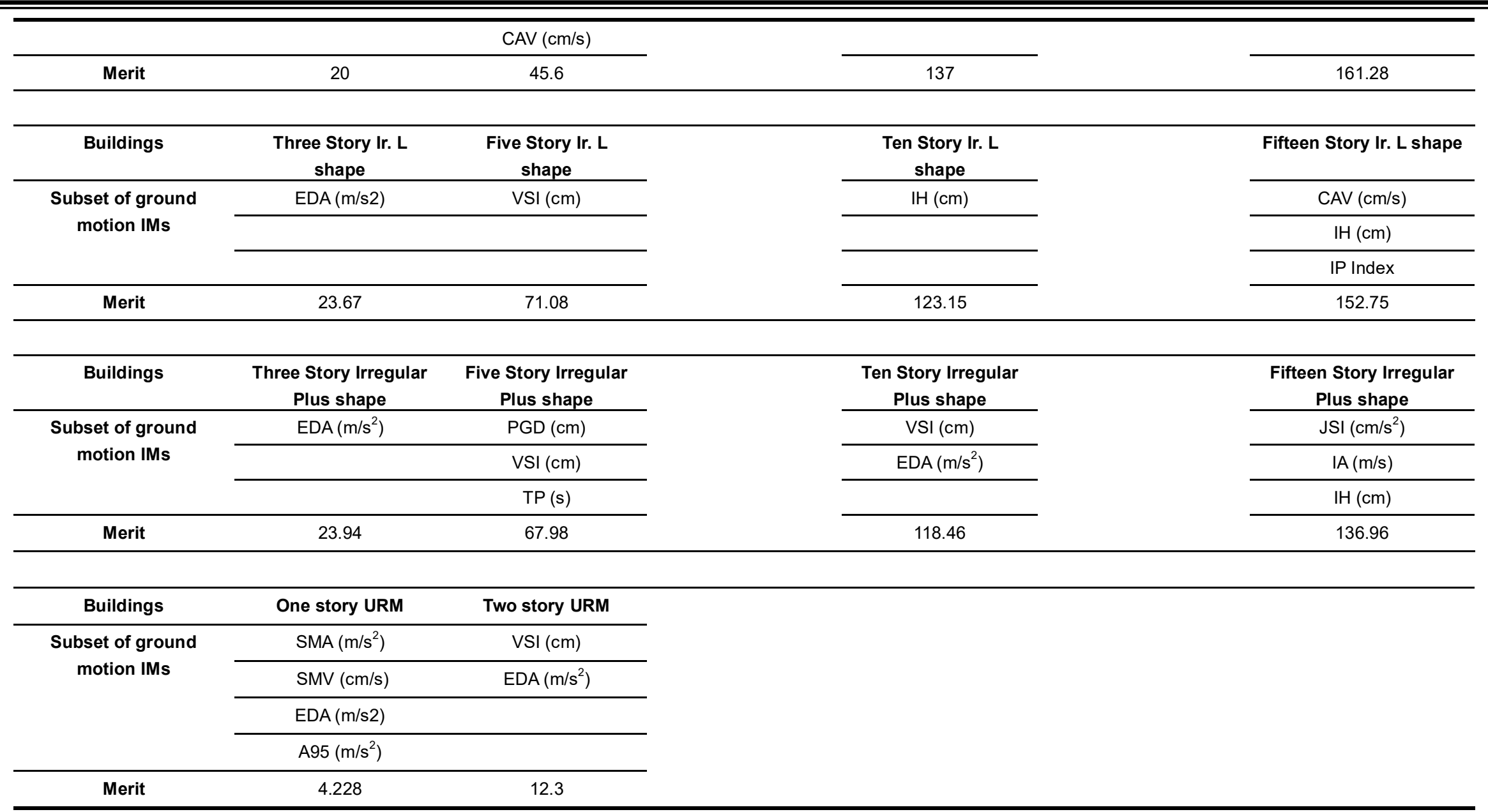

a.yaseen@uod.ac, mezgeen@uod.ac, yaman.alkamaki@uod.ac

${ }^{1}$ Corresponding author: College of Engineering, University of Duhok, Kurdistan Region, Iraq 
Journal of University of Duhok, Vol. 23, No.2 (Pure and Eng. Sciences), Pp 254-277, 2020 (Special Issue)

$3^{\text {rd }}$ international conference on recent innovations in engineering (ICRIE) Duhok, September 9-10-2020

Table A7 Subsets of ground-motion IMs obtained for three and five story RC frame buildings from the second stage of feature selection process (subset merging scheme) (Twenty-seven earthquake record dataset)

\begin{tabular}{|c|c|c|c|c|c|c|c|}
\hline $\begin{array}{c}\text { Three story RC } \\
\text { frame }\end{array}$ & $\begin{array}{c}\text { Subset of ground } \\
\text { motion IMs }\end{array}$ & Merit & $\begin{array}{l}\text { Learning } \\
\text { algorithm }\end{array}$ & Five story RC frame & $\begin{array}{c}\text { Subset of ground } \\
\text { motion IMs }\end{array}$ & Merit & $\begin{array}{l}\text { Learning } \\
\text { algorithm }\end{array}$ \\
\hline \multirow[t]{3}{*}{ Regular } & $\mathrm{IAJ}\left(\mathrm{m} / \mathrm{s}^{2}\right)$ & \multirow[t]{3}{*}{25.94} & \multirow{3}{*}{$\begin{array}{l}\text { Multilayer } \\
\text { Perceptron }\end{array}$} & \multirow[t]{4}{*}{ Regular } & $\mathrm{Sj}$, avg $\left(\mathrm{cm} / \mathrm{s}^{3}\right)$ & \multirow[t]{4}{*}{46.98} & \multirow{4}{*}{$\begin{array}{l}\text { Multilayer } \\
\text { Perceptron }\end{array}$} \\
\hline & $\mathrm{ASI}(\mathrm{m} / \mathrm{s})$ & & & & $\operatorname{ARMS}\left(\mathrm{m} / \mathrm{s}^{2}\right)$ & & \\
\hline & $\mathrm{IH}(\mathrm{cm})$ & & & & $\mathrm{TP}(\mathrm{s})$ & & \\
\hline \multirow{2}{*}{$\begin{array}{l}\text { Irregular Set } \\
\text { Back } 1 \text { shape }\end{array}$} & $\mathrm{JE}\left(\mathrm{cm} / \mathrm{s}^{3}\right)^{2}$ & \multirow[t]{2}{*}{23.1} & \multirow[t]{2}{*}{ Random Tree } & & Sa,ave. $\left(\mathrm{cm} / \mathrm{s}^{2}\right)$ & & \\
\hline & $\mathrm{PGA}\left(\mathrm{m} / \mathrm{s}^{2}\right)$ & & & \multirow{5}{*}{$\begin{array}{c}\text { Irregular Set Back } \\
\text { shape }\end{array}$} & $\mathrm{Sj}$, avg $\left(\mathrm{cm} / \mathrm{s}^{3}\right)$ & \multirow[t]{5}{*}{52.76} & \multirow{5}{*}{$\begin{array}{l}\text { Multilayer } \\
\text { Perceptron }\end{array}$} \\
\hline \multirow{2}{*}{$\begin{array}{l}\text { Irregular Set } \\
\text { Back }^{2} \text { shape }\end{array}$} & $\mathrm{JSI}\left(\mathrm{cm} / \mathrm{s}^{2}\right)$ & \multirow[t]{2}{*}{21.5} & \multirow{2}{*}{$\begin{array}{l}\text { Multilayer } \\
\text { Perceptron }\end{array}$} & & $\mathrm{VSI}(\mathrm{cm})$ & & \\
\hline & $\mathrm{ASI}(\mathrm{m} / \mathrm{s})$ & & & & $\mathrm{IH}(\mathrm{cm})$ & & \\
\hline \multirow[t]{3}{*}{ Irregular I shape } & $\mathrm{JSI}\left(\mathrm{cm} / \mathrm{s}^{2}\right)$ & \multirow[t]{3}{*}{16.6} & \multirow{3}{*}{$\begin{array}{l}\text { Multilayer } \\
\text { Perceptron }\end{array}$} & & $\mathrm{TP}(\mathrm{s})$ & & \\
\hline & $\mathrm{ASI}(\mathrm{m} / \mathrm{s})$ & & & & Sa,ave. $\left(\mathrm{cm} / \mathrm{s}^{2}\right)$ & & \\
\hline & $\operatorname{EDA}\left(\mathrm{m} / \mathrm{s}^{2}\right)$ & & & \multirow{5}{*}{$\begin{array}{c}\text { Irregular Set Back } \\
\text { shape }\end{array}$} & $\mathrm{JSI}\left(\mathrm{cm} / \mathrm{s}^{2}\right)$ & \multirow[t]{5}{*}{54.98} & \multirow[t]{5}{*}{ Random Tree } \\
\hline \multirow[t]{4}{*}{ Irregular L shape } & $\mathrm{JSI}\left(\mathrm{cm} / \mathrm{s}^{2}\right)$ & 24.5 & \multirow{4}{*}{$\begin{array}{l}\text { Multilayer } \\
\text { Perceptron }\end{array}$} & & $\mathrm{Sj}, \operatorname{avg}\left(\mathrm{cm} / \mathrm{s}^{3}\right)$ & & \\
\hline & VRMS $(\mathrm{cm} / \mathrm{s})$ & & & & $\operatorname{PGA}\left(\mathrm{m} / \mathrm{s}^{2}\right)$ & & \\
\hline & $\mathrm{ASI}(\mathrm{m} / \mathrm{s})$ & & & & A95 $\left(\mathrm{m} / \mathrm{s}^{2}\right)$ & & \\
\hline & $\mathrm{IH}(\mathrm{cm})$ & & & & $\mathrm{TP}(\mathrm{s})$ & & \\
\hline \multirow{8}{*}{$\begin{array}{l}\text { Irregular Plus } \\
\text { shape }\end{array}$} & $\mathrm{JE}\left(\mathrm{cm} / \mathrm{s}^{3}\right)^{2}$ & 25.73 & \multirow{8}{*}{$\begin{array}{l}\text { Multilayer } \\
\text { Perceptron }\end{array}$} & \multirow[t]{4}{*}{ Irregular I shape } & $\mathrm{Sj}, \mathrm{avg}\left(\mathrm{cm} / \mathrm{s}^{3}\right)$ & \multirow[t]{4}{*}{41.97} & \multirow{4}{*}{$\begin{array}{l}\text { Multilayer } \\
\text { Perceptron }\end{array}$} \\
\hline & ASI (m/s) & & & & $\operatorname{PGA}\left(\mathrm{m} / \mathrm{s}^{2}\right)$ & & \\
\hline & & & & & PGD (cm) & & \\
\hline & & & & & $\operatorname{ARMS}\left(\mathrm{m} / \mathrm{s}^{2}\right)$ & & \\
\hline & & & & \multirow[t]{2}{*}{ Irregular L shape } & Sj, avg $\left(\mathrm{cm} / \mathrm{s}^{3}\right)$ & \multirow[t]{2}{*}{54.47} & \multirow[t]{2}{*}{ Random Tree } \\
\hline & & & & & $\mathrm{TP}(\mathrm{s})$ & & \\
\hline & & & & \multirow[t]{2}{*}{ Irregular Plus shape } & $\mathrm{Sj}$, avg $\left(\mathrm{cm} / \mathrm{s}^{3}\right)$ & \multirow[t]{2}{*}{50} & Random Tree \\
\hline & & & & & $\mathrm{TP}(\mathrm{s})$ & & \\
\hline
\end{tabular}

a.yaseen@uod.ac, mezgeen@uod.ac, yaman.alkamaki@uod.ac

${ }^{1}$ Corresponding author: College of Engineering, University of Duhok, Kurdistan Region, Iraq 
Table (A8): Subsets of ground motion IMs obtained for ten and fifteen story RC frame buildings from the second stage of feature selection process (submerging scheme) (Twenty-seven earthquake record dataset)

\begin{tabular}{|c|c|c|c|c|c|c|c|}
\hline $\begin{array}{c}\text { Ten story RC } \\
\text { frame }\end{array}$ & $\begin{array}{c}\text { Subset of ground } \\
\text { motion IMs }\end{array}$ & Merit & $\begin{array}{r}\text { Learning } \\
\text { algorithm } \\
\end{array}$ & Fifteen story RC frame & $\begin{array}{c}\text { Subset of ground } \\
\text { motion IMs }\end{array}$ & Merit & $\begin{array}{l}\text { Learning } \\
\text { algorithm } \\
\end{array}$ \\
\hline \multirow[t]{3}{*}{ Regular } & PGD $(\mathrm{cm})$ & 85.03 & \multirow{3}{*}{$\begin{array}{l}\text { Multilayer } \\
\text { Perceptron }\end{array}$} & Regular & $\mathrm{JSI}\left(\mathrm{cm} / \mathrm{s}^{2}\right)$ & \multirow[t]{4}{*}{101.65} & \multirow[t]{4}{*}{ Random Tree } \\
\hline & $\mathrm{IH}(\mathrm{cm})$ & & & & $\mathrm{IA}(\mathrm{m} / \mathrm{s})$ & & \\
\hline & $\operatorname{EDA}\left(\mathrm{m} / \mathrm{s}^{2}\right)$ & & & & $\mathrm{IH}(\mathrm{cm})$ & & \\
\hline $\begin{array}{l}\text { Irregular Set } \\
\text { Back }^{1} \text { shape }\end{array}$ & $\mathrm{IH}(\mathrm{cm})$ & 91 & Random Tree & & IP Index & & \\
\hline $\begin{array}{l}\text { Irregular Set } \\
\text { Back }^{2} \text { shape }\end{array}$ & $\mathrm{IH}(\mathrm{cm})$ & 114.7 & Random Tree & $\begin{array}{c}\text { Irregular Set Back }{ }^{1} \\
\text { shape }\end{array}$ & $\mathrm{IA}(\mathrm{m} / \mathrm{s})$ & 106.8 & Random Tree \\
\hline \multirow[t]{4}{*}{ Irregular I shape } & PGD (cm) & \multirow[t]{4}{*}{104.23} & \multirow[t]{4}{*}{ Random Tree } & & $\mathrm{CAV}(\mathrm{cm} / \mathrm{s})$ & & \\
\hline & VRMS $(\mathrm{cm} / \mathrm{s})$ & & & & $\mathrm{VSI}(\mathrm{cm})$ & & \\
\hline & $\mathrm{VSI}(\mathrm{cm})$ & & & & $\mathrm{IH}(\mathrm{cm})$ & & \\
\hline & $\mathrm{IH}(\mathrm{cm})$ & & & Irregular Set Back ${ }^{2}$ & $\mathrm{CAV}(\mathrm{cm} / \mathrm{s})$ & 104.2 & Random Tree \\
\hline \multirow[t]{2}{*}{ Irregular L shape } & PGD $(\mathrm{cm})$ & 107.8 & \multirow{2}{*}{$\begin{array}{l}\text { Multilayer } \\
\text { Perceptron }\end{array}$} & shape & $\mathrm{IH}(\mathrm{cm})$ & & \\
\hline & $\mathrm{IH}(\mathrm{cm})$ & & & Irregular I shape & $\mathrm{IH}(\mathrm{cm})$ & 130 & Random Tree \\
\hline \multirow{5}{*}{$\begin{array}{l}\text { Irregular Plus } \\
\text { shape }\end{array}$} & PGD $(\mathrm{cm})$ & 101.28 & \multirow{3}{*}{$\begin{array}{l}\text { Multilayer } \\
\text { Perceptron }\end{array}$} & & $\mathrm{IH}(\mathrm{cm})$ & & Perceptron \\
\hline & $\mathrm{IH}(\mathrm{cm})$ & & & Irregular Plus shape & $\mathrm{CAV}(\mathrm{cm} / \mathrm{s})$ & 129.5 & Random Tree \\
\hline & $\mathrm{EDA}(\mathrm{m} / \mathrm{s} 2)$ & & & & $\mathrm{ASI}(\mathrm{m} / \mathrm{s})$ & & \\
\hline & & & & & $\mathrm{IH}(\mathrm{cm})$ & & \\
\hline & & & & & IP Index & & \\
\hline
\end{tabular}

a.yaseen@uod.ac, mezgeen@uod.ac, yaman.alkamaki@uod.ac

${ }^{1}$ Corresponding author: College of Engineering, University of Duhok, Kurdistan Region, Iraq 